\title{
A COMPARATIVE ANALYSIS OF TEACHERS' BELIEFS ABOUT THE ASSESSMENT OF 4TH GRADE-EFL STUDENTS IN TURKEY, ITALY AND FINLAND
}

\author{
Nilay Ceylan Çakır ${ }^{1}$, \\ Zübeyde Sinem Genç $c^{2 i}$ \\ İ̇znik İlçe Milli Egitim Mudurlugu, \\ Turkey \\ ${ }^{2}$ Bursa Uludag University, \\ Turkey
}

\begin{abstract}
:
The aim of this study is to find out the beliefs of the foreign language teachers about the ways and types of assessment tools, assessment activities and exercises used for $4^{\text {th }}$ gradeEFL students in Turkey, Italy and Finland. A total of 170 English language teachers (89 in Turkey, 40 in Italy and 41 in Finland) constituted the sample of the study. For data collection, a questionnaire with two parts was used. The quantitative data collected through the questionnaire were analyzed using descriptive statistics (frequency, percentage, mean, standard deviation) and one-way ANOVA. The results of the study revealed important points about assessing foreign language skills at primary school level. Turkish, Italian and Finnish teachers believed that more student-centered and formativebased assessment procedures should be used for 4th grade-students who learn English as a foreign language. The results also showed that teachers' beliefs about the types of assessment, the content/skills-focus and the need for different kinds of exercises to assess 4th-graders did not differ significantly in terms of the country. However, teachers' general beliefs about the assessment of $4^{\text {th }}$-grade students' foreign language differed significantly in terms of the country. The post-hoc analysis showed that Italian teachers' general beliefs about the assessment procedures for $4^{\text {th }}$ grade students' foreign language was significantly higher than Finnish and Turkish teachers' general beliefs.
\end{abstract}

Keywords: assessment, learners of English as a foreign language, teachers' beliefs, Turkey Finland, Italy

\section{Introduction}

Assessment and evaluation have always received attention in the field of English language teaching, especially for language policy, methodology and curriculum design

i Correspondence: e-mail zsgenc@uludag.edu.tr zgenc@yahoo.com 
in language teaching, in language learning and also in language teachers' professional development. Most recently, assessment as a part of curriculum of all subjects have received much greater attention by language teachers and curriculum specialists due to its potential to affect the ways of instruction and evaluation of language learner (Dochy, 2001; Remesal, 2011). Assessment has a critical role and multidimensional functions in terms of enabling teachers to know their learners, determine the learning objectives, design the learning environment, select the appropriate materials and provide feedback to learners.

Teaching English as a foreign language (EFL) at primary school level has gained importance in Turkey as it has all around the world. With the recent changes in the Turkish educational system $(4+4+4)$, English language lesson has become mandatory for $2^{\text {nd }}, 3^{\text {rd }}$ and $4^{\text {th }}$ grades at primary schools. Accordingly, English language teaching programs have been redesigned taking the learners' needs into consideration. The functions which are based on communicative competence like telling, asking, responding, naming etc. are prepared according to the A1 (basic user) level of CEFR at $2^{\text {nd }}, 3^{\text {rd }}$ and $4^{\text {th }}$ grades $(M E B, 2018)$. The new curriculum also includes some methods about evaluation such as student portfolio, self-assessment and peer-assessment. Previous studies in Turkey show that although there is a program suggested by authorities for schools, teachers still use traditional methods like pen and paper tests to assess their students; self-assessment is not applied at schools and the portfolio assessment is still being neglected by the teachers (Kırkgöz \& Ağçam, 2012; Öz, 2014; Tatl1, 2014). Moreover, the content of the tests is based on grammar and vocabulary items and most of the assessment procedures ignore listening and speaking skills. In the studies from different parts of the world, the results indicate that in the assessment of young learners' foreign language competence, traditional written-oral assessment by numerical grades is still carried out.

Even though teachers design and plan their teaching processes in line with the curricula, a variety of factors influence their choice of assessment type and procedures. Teachers' beliefs regarding language teaching and learning, their experience in the teaching profession, students' characteristics and also the school type were previously reported as the determinants of teachers' selection or choice of assessment (Broadfoot \& Black, 2004; Pajares, 1992). Another important issue regarding the selection of assessment tools and ways is associated with teachers' conceptions and attitudes. Teachers' attitudes toward assessment influence the ways in which the assessment happens (Griffiths, Gore \& Ladwig, 2006). Teachers' perceptions and beliefs in relation to assessment practices have a considerable effect on the ways they use in teaching and their assessment practices as well as teachers' behaviors and students' performance (Jia, Eslami \& Burlbaw, 2006; Johnson, 1992).

\subsection{Purpose of the Study}

The aim of this study is to find out what foreign language teachers' beliefs are with regard to the assessment of 4th-grade EFL learners and the ways and types of assessment tools, 
assessment activities and exercises used for these students in Turkey, Italy and Finland. The study also explores whether there are significant differences between the beliefs of Turkish, Italian and Finnish EFL teachers. The research focused on 4th-grade level because formal assessment starts at 4th grades in Turkey. Various aspects of the assessment system (types, activities, content, skills etc.) were analyzed in detail and compared in these three countries.

\subsection{Significance of the Study}

Turkey is in the process of being a member of the European Union and makes adaptation and reform attempts in all areas of education to be in line with EU criteria. Designing the language curricula according to CEFR is one of the steps taken for this adaptation attempts. Language education in European countries has already been implementing CEFR criteria for a long time. Teachers' perspective of assessment, the context in which they implement the assessment and curriculum / syllabus followed are the critical factors which are influential on the selection and implementation of assessment. How this is different from classroom to classroom in different countries is still in question. Therefore, comparing teachers' beliefs regarding assessment in Turkish EFL classes and European EFL classes help to understand how Turkish EFL teachers' beliefs about assessment differ from European teachers.

\subsection{Research Questions}

The following research questions were addressed throughout the study:

1) What are the EFL teachers' beliefs about the assessment of 4 th year- EFL learners at primary school level in Turkey, Italy and Finland?

2) Are there significant differences between Turkish, Italian and Finnish EFL teachers' beliefs about the assessment of 4th year- EFL learners at primary school level?

This study especially scrutinizes EFL teachers' general beliefs regarding the assessment of 4 th -grade learners, the types of assessment, the content/skill-focus in assessment, and the kinds of exercises used.

\section{Literature Review}

Assessment is a systematic way of collecting, reviewing and using a lot of information regarding to education program in order to improve learning (Palomba and Banta, 1999). In addition to collection of systematic and related information, Anandan (2015) indicates that various tools and techniques as a part of assessment help educators to document, measure and evaluate learners' readiness, progress and skills. Assessment is being used for many purposes in educational settings and procedures. Wiesnerová (2013) grouped the functions of assessment as informative, corrective and motivational. Liljedahl (2010) asserts the main purposes of assessment as communication, valuing what is taught, reporting out and not sorting / not ranking. As understood from the definition and its 
area of usage, assessment provides information and feedback not only for the students' progress and development in various areas (e.g. knowledge, skills, beliefs, values etc.), but also for curriculum and course implementation (e.g. book, plans, activities, methods etc.) (Anandan, 2015; Ioannou - Georgiou, 2003; Nasab, 2015; Palomba \& Banta, 1999).

In language classes, assessment is an integral part of language teaching and learning due to the fact that the information collected through assessment gives idea about the quality of instruction and progress of students in terms of having adequate knowledge and skills in language (Doğandere, 2006). Assessment in English language classes is generally used for educational purposes such as placement, guidance, prediction, diagnosis, selection, evaluation, or other administrative purposes (Lamprianou \& Athanasou, 2009). Thus, assessment is used for many purposes and to take different decisions either in process, or product or in both in language classes. In this sense, teachers have critical roles for making assessment process effective and useful. Cumming (2009) indicates that as an assessor, teachers' role in assessment is rather complex and includes several components as monitoring and reporting students' achievement, diagnosing students' learning difficulties, and making student groups for a specific task or placement. Teachers make use of a variety of assessment tools in language classes which help them observe the strengths and weaknesses of teaching and learning process, and also provide evidence for re-designing their instructions.

\subsection{Teachers' Beliefs about Assessment}

In the educational processes, teachers have several roles to make the process effective and fruitful. One of these roles is associated with the assessment. Cumming (2009) believes that teachers' role for assessment (as an assessor) is rather complex and consists of many sub-components. In more specific to language teaching, teachers in language classes are generally and routinely expected to monitor and report students' achievement (e.g. written and oral communication skills), diagnose students' learning difficulties, and make student groups for a specific task or placement, etc. Rea-Dickins (2004) says that the teacher role in assessment as a vital part of learning makes the teacher agents of assessment who observes, evaluates and interprets students' achievement for improving their attainment.

In order to monitor the learning process and students' progress and determine whether the pre-determined goals are attained, teachers make use of a variety of assessment procedures and tools. They may prefer to use more teacher-based and standard-based tests, but in this case, the assessment will be more outcome-based and teachers will focus on the final products of the teaching rather than process. In a large scale-testing, the assessor may sometimes not be a teacher of the assessed students and not aware of students' individual differences and also the classroom context, which may result in as a matter of fairness (Fulcher \& Davidson, 2007).

On the other hand, in the classroom assessment which is mostly formative in nature and a combination of various assessment procedures, teachers focus more on authentic and informal tasks as well as seek for multi-faced reality. In this type of 
assessment, teachers (as an assessor) are more familiar with the classroom context, aware of learners' differences and utilized wide range of information / evidences to judge learners' performance. In such assessment, teachers interact with learners for the reason of revealing learners' current ability so as to take a step for further learning (Fulcher \& Davidson, 2007). Assessment and teaching are interwoven in alternative assessment, which treats the learning as an active process (Ayas, 2014). In such practices, students are never grouped based on their performance, teachers emphasize what, how and why the students learn, students are given immediate feedback and teachers look for alternative learning strategies for achieving the learning goals based on the feedback emerged from the assessment (Anderson, 1988).

Figure 1: Assessment for and of Learning

\begin{tabular}{|c|c|}
\hline $\begin{array}{l}\text { Assessment for Learning } \\
\text { (formative assessment) }\end{array}$ & $\begin{array}{l}\text { Assessment of Learning } \\
\text { (summative assessment) }\end{array}$ \\
\hline $\begin{array}{l}\text { Checks learning to decide what to do next, then } \\
\text { provides suggestions of what to do; teaching and } \\
\text { learning are indistinguishable from assessment }\end{array}$ & Checks what has been learned to date \\
\hline $\begin{array}{l}\text { Is designed to help educators and students } \\
\text { improve learning }\end{array}$ & $\begin{array}{l}\text { Is designed for the information of those not } \\
\text { directly involved in daily learning and teaching } \\
\text { (e.g., school administration, parents, school board, } \\
\text { Alberta Education, post-secondary institutions) in } \\
\text { addition to educators and students }\end{array}$ \\
\hline $\begin{array}{l}\text { Is used continually to provide descriptive } \\
\text { feedback }\end{array}$ & Is presented in a periodic report \\
\hline $\begin{array}{l}\text { Usually uses detailed, specific and descriptive } \\
\text { feedback, in a formal or informal report }\end{array}$ & $\begin{array}{l}\text { Usually compiles data into a single number, score } \\
\text { or mark as a formal report }\end{array}$ \\
\hline Is not reported as part of an achievement grade & Is reported as part of an achievement grade \\
\hline $\begin{array}{l}\text { Usually focuses on improvement, compared with } \\
\text { the student's previous best }\end{array}$ & $\begin{array}{l}\text { Usually compares the student's learning with } \\
\text { other students' learning, e.g., norm-referenced - } \\
\text { making learning highly competitive, or the } \\
\text { standard for a grade level; e.g., criterion - } \\
\text { referenced - making learning more collaborative } \\
\text { and individually focused }\end{array}$ \\
\hline Must involve the student & Does not always involve the student \\
\hline
\end{tabular}

(From Sutton (2001) as cited in Alberta Education 2008)

Assessment in language classes could be used for different purposes. A discussion on assessment for learning (formative assessment) and assessment of learning (summative assessment) have been observed in the language assessment literature. Sutton (2001: 4, as cited in Alberta Education, 2008, p. 4) compares assessment for and of learning as given in Figure 1.

Assessment for learning that associates assessment with formative purposes (so called formative assessment) is mainly undertaken to improve the quality of teaching and learning process, to provide feedback to both students and teaching process and to focus 
upon improvement and process. Ongoing exchange of information regarding learning between student and student, and also between teacher and students is the main character of this type of assessment (Alberta Education, 2008). On the other hand, assessment of learning that associates assessment with summative purposes (so called summative assessment) is generally used for providing reports on whether students attain the objectives at the end of the course of the subject and focus mainly on grading students' achievements and products. Students' achievement at a given point is assessed or graded in this type of assessment (Alberta Education, 2008).

Similarly, Öz (2014) indicates that the paradigm shift has been observed in the use of assessment in educational practices in which the students' learning and assessment are considered to be interconnected and inseparable from each other. As an integrated part of teaching process, in this new trend, assessment is conceived as a process in order to support students' learning.

Teachers use several assessment tools in language classes to develop learners' language skills and helping them monitor their own learning. At the same time, various usage of assessment tools could help them observe the strengths and weaknesses of teaching and learning process, and also provide evidence for re-designing their instruction. Even though teachers are designing and planning their teaching processes in line with the curricula, a variety of factors influence their choice of assessment types and procedures.

Teachers' beliefs regarding language teaching and learning, their experience in the teaching profession, students' characteristics and also the school types are previously reported as the determinants of teachers' selection or choice of assessment (Broadfoot \& Black, 2004; Pajares, 1992). Mertler (1998) reports differences in school levels (elementary, middle and high), years of experience and school location (urban, sub-urban and rural) as the factors impacting teachers' assessment practices. Teachers' perceptions and beliefs in relation to assessment practices have a considerable effect on the ways they used in teaching and their assessment practices as well as teachers' behavior and students' performance (Jia, Eslami \& Burlbaw, 2006; Johnson, 1992). In addition, as pointed out in the current national and international literature on language teaching and assessment, teachers' conception and perception of assessment (Gökçe, 2014; Jannati, 2012; Shim, 2009; Öz, 2014) and also attitudes (Brown, 2008) influence their choice of assessment as well as their instructions and assessment practices.

Emphasizing the role of teachers' beliefs in the selection of assessment, Thomas (2012) revealed seven beliefs on classroom assessment based on the review of available literature. These beliefs are as below:

"(1) Assessments which take place informally in the class are the best ways of assessing students' performance, (2) Informal assessments are a waste of teaching time, (3) Assessment is a joint venture between teachers and parents, (4) Assessment encourages students to look critically their own classroom performances, (5) Assessments in the form of direct observation, reduces students' academic achievements, (6) Assessment pressurizes 
teachers to complete their syllabi, (7) Assessments, in the form of formal tests, makes a negligible contribution to student learning." (p.106)

Song and Koh (2010) claim that teachers' beliefs about student learning often influence their assessment practices. They have conducted a study to examine the relationship between teachers' beliefs about students' learning and their formative assessment practices and found that teachers' beliefs about students' learning influenced their FA practices; e.g. peer / self -assessment, formative feedback and clarity of task. Their study has also pointed out that teachers' personal interest, tension between assessment of and for learning and their beliefs regarding the feedback and diagnosis of learning needs were the factors behind the teachers' beliefs about students' learning that impacted their choice of FA. Similarly, Guskey (2002) also indicates that teachers' assessment literacy and their beliefs about students' learning influenced mainly their FA practices.

Theory in relation to a specific topic or subject may not be sometimes appropriate and applicable in a particular context due to several reasons, e.g. class size, teachers' experience etc. In this case, teachers tend to select among the available tools based upon their experience and background, course content, students' readiness level and so on. Teachers may have a positive perception of any type of assessment (e.g. formative assessment) but they do not tend to use such assessment due to work load, overcrowded classroom (Büyükkarcl, 2014), difficulty with its administration and lack of time (Veal, 1988).

Assessment in a language class is a challenging and complicated task; thus effective use of assessment procedures require knowledge and mastery of assessment strategies. Teachers' perceptions of and beliefs about a particular assessment type are critical for their selection of such assessment, but should not be unique sources. Teachers' knowledge on the assessment and awareness of how the assessment improves students' performance and teaching - learning processes should also be considered (Thomas, 2012).

\subsection{Research on Teachers' Perceptions of and Beliefs about Assessment}

Ayas (2014) conducted a study to investigate English teachers' conceptions regarding the assessment and choices of assessment tasks. As the data collection instrument, Teachers' Conceptions of Assessment Questionnaire (TCoA-IIIA) was used. The instrument was applied to 43 teachers teaching English as a foreign language in primary schools. The results of the study pointed out that English teachers tended to use various assessment tools and strategies in practice. Most of them preferred to use alternative assessment procedures even though some preferred to use traditional ones. No contradiction was observed between teachers' perceived preferences and conceptions regarding assessment. Interestingly, even though there seemed to be no contradiction, the teachers' actual use of assessment procedures was observed to be different from their perceived preferences and their conception of the assessment. The assessment tools that teachers used in practice were teacher-made written test, standardized tests, question - answer, 
written works by students, self- and peer- assessment, portfolios, and planned observation. Teachers conceived the assessment in three categories as improvement, student accountability and school accountability.

Öz (2014) examined Turkish EFL teachers' assessment for learning practices and preferences of assessment methods in EFL classes. He also examined whether teachers' practices of assessment or learning differed with regard to gender, years of teaching experience, school type (public vs. private). 120 Turkish EFL teachers participated in the study and filled out an online questionnaire. The results pointed out that EFL teachers most frequently preferred to use fill-in-the-blank, multiple choices, true-false, matching and short-answers as assessment methods. They more tended to implement traditional methods rather than alternative ones (e.g. portfolios, performance assessment and so on.). Teachers' scaffolding practices and perceived monitoring were reported to be as high level. Teachers' assessment practices in relation to monitoring in support of student learning significantly differed with regard to gender, school type (public vs. private) and years of teaching experience.

Kirkgoz, Babanoğlu and Ağçam (2017) investigated EFL teachers' perceptions of assessment and also their use of assessment and question types in assessment practices in their language classes in primary schools. A total of 56 EFL teachers drawn from 42 public primary schools were selected as the sample of the study. In order to elicit EFL teachers' perceptions and practices related to foreign language assessment in $4^{\text {th }}$ to $6^{\text {th }}$ grades, a questionnaire was used as data collection tool. The results revealed that almost all the teachers believed in the importance of using assessment in foreign language classes. The teachers stated they assessed students in order to track their development in foreign language, determine whether the objectives in the course curricula were attained, evaluate the performance of both the teacher and students, and to increase the quality of teaching. It has been also stated that the assessment provided feedback not only for the teachers about their teaching but also for the students about their progress and about the appropriateness of approaches, methods and techniques used in language teaching, suggesting necessary changes (if needed) for the implementation. The most frequently assessment tools used in language classes were paper-pencil tests, in-class observations and performance tasks. In order to evaluate the students' attainments better in English language, teachers preferred to use performance-based and communication-based assessment types more frequently than traditional assessment types. Oral exams, presentations, portfolios, projects and quizzes were less frequently used assessment tools in English language classes.

Kibar (2018) conducted a study aiming at determining the differences between perceptions of in-service and pre-service teachers on classroom-based language assessment. A total of 40 in-service English teachers and 99 pre-service English teachers in Ankara participated in the study. The participants were asked to complete a questionnaire to reflect their perceptions on assessment in language classes. The results pointed out that there was a significant difference between two groups of teachers regarding classroom - based assessment. The participants were observed to have positive 
perceptions with regard to classroom-based assessment. Pre-service teachers' teaching experience made a difference on the teachers' perceptions. On the other hand, the preservice teachers perceptions of classroom based assessment did not significantly differ in terms of their gender and grade point average.

Önalan and Karagül (2018) examined teachers' beliefs about the use of assessment in EFL classes, and also the effect of teachers' years of teaching experiences and the departments they graduated. 70 Turkish EFL teachers selected from prep school of a university completed a questionnaire. The results of the study pointed out that Turkish EFL teachers mostly tended to use assessment for formative purposes. Self-assessment was believed to be an important assessment procedure in teaching English as a foreign language. Teachers' beliefs about the use of assessment did not significantly differ in terms of neither years of teaching experience (novice vs. two or more years) nor the department (ELT vs. others) graduated.

Şahinkarakaş (2012) examined EFL teachers' conceptions of assessment and the effect of teaching experience on their conceptions of assessment. A total of 53 prospective teachers in the department of English language teaching and 47 EFL teachers having a lot of teaching experiences participated in the study. Teachers were given a statement to indicate their metaphorical images for assessment and then required to give their reasons for this metaphor. The results of the study showed that teachers' produced 73 metaphors categorized in four themes; assessment as a formative tool, a summative tool, something agitating and a sign of self-efficacy. The metaphors, which were categorized under the assessment as a formative tool, were related to an ongoing process, a way to promote learning through feedback and to diagnose learners' weaknesses and strengths. The metaphors categorized under the assessment as a summative tool were related to the end product and grading students' products. Yet, the metaphors categorized under assessment as something agitating were related to fear and difficulty; and the metaphors categorized under the assessment as a sign of self-efficacy were related to reflection of oneself and personal satisfaction.

Gökçe (2014) examined EFL teachers' perceptions of formative assessment (FA) and also compared their perceptions of FA in terms of school type (public vs. private). A total of 100 EFL teachers were selected from 39 schools (primary to high school) in Turkey. The results pointed out that most of the EFL teachers emphasized the importance of using FA due to its contribution to students' learning in English. Furthermore, the teachers believed in that the students should be aware of why they are being assessed and FA helped promote learning in language classes. More than half of the EFL teachers in public schools emphasized the value of FA that promotes learning, they benefited from FA in order to re-design and develop their own teaching of English. Private school EFL teachers also believed in that the primary aim of FA was to promote learning. They claimed that students could progress on their own. The data also revealed that the private school EFL teachers used FA more effectively than those in public schools did.

Gattullo (2000) undertook a study with four teachers, three generalists, one specialist and also 86 children (at the age of 9 and 10) studying English as a foreign 
language since they were 8 years-old. In this study, Gattulo (2000) aimed at identifying interpretation and implementation of assessment in the final years of primary schools in Italy, dimensions of formative assessment, good practices used as formative assessment and differences between formative and summative assessment. For data sources, classroom observations, interviews with teachers, assessment materials used for teaching English as a foreign language and student questionnaire were utilized. The results pointed out that the teachers used formative assessment for the purpose of correcting, questioning, metacognitive questioning, judging, observing process, examining products, rewarding, clarifying, task criteria. Questioning in formative assessment was used for two purposes; correcting or making counter-suggesting and providing input, response and feedback. Several weaknesses in using formative assessment in classroom teaching were revealed in the observations, interviews and questionnaires as the development of more structural ways in oral abilities, providing action and feedback for self-repair and developing procedures in order to record students' performances.

Wewer (2014) designed a mixed design study to investigate teachers' assessment practices in second language classes in primary schools in Finland. In addition, parents' and pupils' perception of language assessment and computer simulation program (LangPerform) were also examined in the study. A total of 42 teachers serving bilingual content instruction, 109 children drawn from $3^{\text {rd }}$ to $5^{\text {th }}$ grades and also 99 parents participated in the study. Mixed type data were collected; experimentation, questionnaire with children and parents, and video interview were used as data sources. The results of the study showed that the most commonly used assessment tools in language classes were teacher observation, dialogic interaction and bilingual tests. On the other hand, the least used assessment tools were peer assessment, simulations and portfolios. Many of them used assessment in order to gather data on the students' attainment and only one third of the teachers scarcely provided feedback to pupils based on the assessment even though teachers perceived the language assessment important.

Jia, Eslami and Burlbaw (2006) designed a qualitative study to examine English teachers' perceptions of classroom-based assessment in reading. In their study, they also aim at presenting teachers' use of classroom based assessment in reading, their understanding in relation to the effectiveness and function of this type of assessment and also the factors associated with this type of assessment. 13 teachers teaching English as a second language in middle (six teachers) and elementary (seven teachers) schools participated in the study. For data sources, classroom observations, interview with English teachers and teachers' assessment materials were used. Content analysis of the data pointed out that teachers valued classroom-based assessment in reading, they believed this type of assessment was valuable and accurate, and also it had high contribution to reading instructions in English classes. As compared to classroom-based assessment, the teachers perceived standardized testing in a negative way and placed very little value in English classes. The factors influencing the use of teachers' assessment in reading were district policies, state-mandated tests and also students' characteristics. 
Halali, Singh, Saeed and Making (2017) designed a survey study to find out EFL teachers' perceptions of using classroom-based assessment in the context of second language acquisition of reading class. Drawn from elementary schools, 28 ELT teachers having ESL certified and at least one year teaching experience participated in the study. The data were collected from the self-reported questionnaire developed by the researchers. The results of the study showed that there were several internal and external factors greatly influencing teachers' perceptions of using classroom-based assessment. Of the factors, facilities, willingness, time management, suitable textbooks and the support provided by the ministry were more observable ones. Teachers believed that using classroom-based assessment helped to improve their formal instruction. Positive internal and external factors promoted teachers' motivation toward classroom-based assessment in reading.

Chan (2008) examined teachers' practices and beliefs about multiple assessment and their difficulties while practicing the assessment in English language teaching in Taiwan. A total of 520 EFL teachers selected from elementary schools in Taiwan participated in the study and completed a questionnaire including various types of items. The results of the study showed that teachers' beliefs and practices of assessment differed in terms of their years of ESL teaching experiences, but did not differ in terms of their ages. Teachers believed that understanding students' learning success and their progress were two main purposes of the assessment. The most frequently used assessment types used by the teachers were paper-pencil tests, classroom observation and task-based assessment. None of the teachers selected traditional types of assessment as the main assessment types. Many of the teachers (\%70) used alternative and traditional types of assessment together. The obstacles influencing teachers' practices of assessment mostly were heavy curriculum content, classroom size (crowded classroom) and considering the assessment as time consuming.

Shim (2009) investigated Korean teachers' perceptions and the use of classroombased assessment in the class where English was taught as a second language in Korean primary schools. In the study, the author examined teachers' assessment in four stages as planning, implementation, monitoring and recording - dissemination. For data collection, a questionnaire including both qualitative and quantitative items reflecting the stages of classroom-assessment was utilized. The results revealed that teachers' firm beliefs about the classroom assessment were influential in their assessment practices, their knowledge of assessment was in a good level and they used appropriate assessment procedures in their operation of classroom assessment practices in the context of English teaching. Although English teachers held many principles in terms of classroom-based assessment, they did not put all into the practice due to heavy work-load, limited funding for teaching foreign language, central bureaucracy of the educational system and overcrowded classroom size. Furthermore, teachers' assessment practices were also affected by their complex relationship with head teachers, other teachers and also parents. 
Jannati (2012) examined Iranian ELT teachers' perceptions and practices in relation to assessment in language classes. A total of 18 ELT teachers in English language institutes in Iran participated in the study. Teachers in the study were divided as low, mid and high in terms of their teaching experience levels. Interviews with teachers were used as data sources in order to address to the aim of the research. Content analysis of the interview transcript pointed out that all teachers were observed to be aware of basic concepts and technologies associated with the assessment in language classes. Teachers' perceptions of assessment were not differentiated with regard to their teaching experience. Teachers at different level of teaching experience attributed the characteristics of good assessment in a different way. The most frequently and commonly reported features were that assessment should assess students' achievement (whether they learn what is expected to be learned) and assessment should be designed based on the objectives of the courses. The assessment practices the teachers used in English language classes were asking questions, asking students to write, storytelling, role-play, group-work and pair-work.

Britton (2015) designed a mixed-method research study to investigate EFL teachers' understanding of assessment for learning in primary schools, implementation of their assessment and the impact of their implementation on the interaction in the class. Various data sources such as class observation, individual and focus group interview and also school documents were utilized. Content analysis of the data showed that teachers' implementation of assessment in the classes of 7-9 year old students and 10-11 year old students were different in terms of setting objectives and expectations, monitoring performance and checking achievement. In addition, empirical data revealed that teachers' use of assessment for learning could have an impact on creating a classroom environment conducive to learning on collaborative interactions. Teachers believed in the special characteristics of teaching English to young learners and their understanding of assessment for learning was in line with theoretical frameworks taken place in the literature.

\section{Method}

\subsection{Research Design}

Quantitative research design was used in the present study. The quantitative data were collected to explore the beliefs of EFL teachers. The research focused on 4th-grade level because the formal assessment starts at 4th-grades in Turkey. Various aspects of the assessment system ( types, activities, content, skills etc.) were analyzed and compared in detail in respect to the three countries under investigation.

\subsection{Data Collection Instrument}

A questionnaire, developed by Brumen et al. (2009), was revised and adapted for the purpose of the present study in order to identify teachers' beliefs about the assessment of 4th-grade EFL students. 
The original instrument was examined item-by-item to determine to what extent the items in the instrument best fit the study's aim and whether a revision was needed based on its most appropriateness. Then, the first revision of the instrument was formulated by an expert on assessment of young EFL learners. The revision was undertaken in terms of language (understanding), format and appropriateness of the items for the study. Thus, some items were found to be irrelevant and excluded, while some items were revised by adapting them into the study context and some items' formats were changed (e.g. from "thick" to "yes - no" response). Furthermore, this version of the instrument was implemented on a pilot group of 30 Turkish EFL teachers teaching $4^{\text {th }}$ graders at primary schools. The purpose of the pilot testing was to shape the instrument's final version. The items in the instrument were revised and changed based on the responses of the teachers and their suggestions. The pilot testing indicated the necessity to revise some items in terms of format, content and structure.

The final version of the instrument was based on the revision provided by the teachers in the pilot testing. The final version of the questionnaire included two main parts with different types of items. The first part was designed to determine the demographics of the teachers. The second part was designed to find out teachers' beliefs about assessment. This part has four sub-sections as beliefs about the types of assessment teachers use for $4^{\text {th }}$ grade students, the content / skills - focus in the assessment of $4^{\text {th }}$ grade students, kinds of exercises teachers used in their assessment of $4^{\text {th }}$ grade students and assessment of students' foreign language. Therefore, the questionnaire consists of 5 demographics (gender, country, teaching experience, level of education, school type and class size) and 4 sub-sections requiring Likert-scale type responses (I fully agree, I agree, I partly agree, I don't agree, I don't agree at all).

\subsection{Participants}

A total of 170 English language teachers participated in the study ( 89 in Turkey, 40 in Italy and 41 in Finland). Teachers who participated in the study were the ones teaching $4^{\text {th }}$ grade English language classes at primary schools and having former experiences at primary and pre-primary schools. Teachers' participation in the study was based on voluntariness. Teachers' ages, experiences, types of schools and such variables were not considered as a variable to include. Therefore, their convenience was mainly considered for inclusion. Teachers were accessed through the use of social networks and teachers' forums.

\subsection{Data Collection Procedures}

Before the instrument was administrated, the necessary permission to undertake the study with EFL teachers at primary schools was obtained from Provincial Directorate of National Education in Bursa, Turkey. Italian and Finnish EFL teachers were contacted through internet and participated in the study based on their voluntariness. After obtaining permission, the questionnaire was first administered on 30 English teachers in Bursa for pilot testing. Having revised the questionnaire, its final version was 
administrated on the target group of teachers face-to-face in Turkey, and it was administered by using of teacher networks and social media in Italy and Finland.

\subsection{Data Analysis}

The data collected through the questionnaire were firstly coded into SPSS.23. The data were cleaned in terms of missing cases, outliers, etc. Later, the cleaned data were analyzed by using descriptive statistics. The results obtained through the analyses were presented using frequencies, percentages, means and standard deviation along with tables, which enabled to make comparison among the countries. In addition to descriptive statistics, one-way-ANOVA was performed for the comparison of data obtained from teachers in three countries.

\section{Results}

\subsection{Demographics of English Teachers}

Of English teachers selected from Turkey, 16 were male, 73 were female; 11 teachers had 0 to 5 years teaching experiences, 61 had 6 to 15 years teaching experiences, 15 had 16 to 24 years teaching experiences and 2 had 24 years or more teaching experiences; 79 teachers had bachelor's degree and 10 had master's degree; and 68 worked at public schools and 3 worked at private schools.

As for the teachers from Italy, 2 were male and 38 were female; 9 teachers had 0 to 5 years teaching experiences, 16 had 6 to 15 years teaching experiences, 12 had 16 to 24 years teaching experiences and 3 had 24 years or more teaching experiences; 23 teachers had bachelor's degree and 17 had master's degree; and 30 worked at public schools and 10 worked at private schools.

All the teachers from Finland were female; 11 teachers had 0 to 5 years teaching experiences, 14 had 6 to 15 years teaching experiences, 13 had 16 to 24 years teaching experiences and 3 had 24 years or more teaching experiences; 7 teachers had bachelor's degree and 34 had master's degree; and 36 worked at public schools and 5 worked at private schools.

Regarding the typical class size, of Turkish participants, 18 teachers indicated a typical class size as less than 20 students, 21 teachers as 20 to 29 students, 18 teachers as 29 to 35 students and 1 teacher as more than 35 students. Of the Italian participants, 12 teachers indicated a typical class size as less than 20 students and 28 teachers as 20 to 29 students. Of the Finnish participants, 21 indicated typical class size as less than 20 students and 20 teachers as 20 to 29 students. Demographics of English teachers are shown in Table 1. 


\begin{tabular}{|c|c|c|c|c|c|c|}
\hline \multicolumn{3}{|c|}{\begin{tabular}{c|c} 
Table 1: Demographic Characteristics c \\
\end{tabular}} & \multicolumn{2}{|c|}{ Italy } & \multicolumn{2}{|c|}{ Finland } \\
\hline & $f(n)$ & $\mathrm{p}(\%)$ & $f(n)$ & $p(\%)$ & $f(n)$ & $\mathrm{p}(\%)$ \\
\hline \multicolumn{7}{|l|}{ Gender } \\
\hline Male & 16 & 17,79 & 2 & 5 & - & 0 \\
\hline Female & 73 & 82 & 38 & 95 & 41 & 100 \\
\hline \multicolumn{7}{|l|}{ Teaching Experience } \\
\hline 0 to 5 years & 11 & 12,35 & 9 & 22,5 & 11 & 26,82 \\
\hline 6 to 15 years & 61 & 68,53 & 16 & 40 & 14 & 34,14 \\
\hline 16 to 24 years & 15 & 16,85 & 12 & 30 & 13 & 31,70 \\
\hline 24 years or more & 2 & 2,24 & 3 & 7,5 & 3 & 7,3 \\
\hline \multicolumn{7}{|l|}{ Level of Education } \\
\hline Bachelor's Degree & 79 & 88.76 & 23 & 57.5 & 7 & 17 \\
\hline Master's Degree & 10 & 11.23 & 17 & 42.5 & 34 & 82.9 \\
\hline \multicolumn{7}{|l|}{ School type } \\
\hline Public & 86 & 96.62 & 30 & 75 & 36 & 87.8 \\
\hline Private & 3 & 3.37 & 10 & 25 & 5 & 12.19 \\
\hline \multicolumn{7}{|l|}{ Number of the Students } \\
\hline Less than 20 students & 18 & 20.22 & 12 & 30 & 21 & 51.22 \\
\hline 20 to 29 students & 52 & 58.42 & 28 & 20 & 20 & 48.78 \\
\hline 29 to 35 students & 18 & 20.22 & - & - & - & - \\
\hline More than 35 students & 1 & 1.12 & - & - & - & - \\
\hline
\end{tabular}

\subsection{Teachers' Beliefs About Assessment}

\subsubsection{Beliefs about the Types of Assessment}

The teachers were asked to indicate their beliefs about the types of assessment to be used for $4^{\text {th }}$ grade students. The responses to beliefs items about the types of assessment are presented in Table 2, Table 3 and Table 4.

For Turkish teachers, based upon the mean average of the items, they agreed that the types of assessment of performance based test $(=4.04)$ and oral interview $(=4.02)$ should be used for $4^{\text {th }}$ graders. They tended to agree that language portfolio $(=3.94)$, teacher own -made paper and pencil test $(=3.87)$, self-assessment $(=3.64)$, peer assessment $(=3.50)$, structured observation $(=3.43)$ and standardize paper and pencil test $(=3.10)$ should be used for $4^{\text {th }}$ grade students.

For Italian teachers, based upon the mean average of the items, they agreed that the types of assessment of oral interview $(=4.42)$ should be used for $4^{\text {th }}$ grade students. They tended to agree that performance-based test $(=3.85)$, structured observation $(=$ $3.85)$, teacher own-made paper and paper and pencil test $(=3.8)$, self-assessment $(=3.75)$, peer assessment $(=3.55)$ and standardized paper and pencil test $(=3.52)$ should be used for $4^{\text {th }}$ grade students.

As for Finnish teachers, based upon the mean average of the items, they agreed that the types of assessment of self-assessment $(=4.26)$, teacher own-made paper and pencil test $(=4.26)$ and oral interview $(=4.02)$ should be used for $4^{\text {th }}$ grade students. They tended to agree that language portfolio $(=3.75)$ and peer-assessment $(=3.63)$ should be used for $4^{\text {th }}$ grade students. 
In order to examine whether teachers' beliefs about using the types of assessment for $4^{\text {th }}$ graders changed according to their country, one way analysis of variance (ANOVA) was performed. ANOVA results are given in Table 5.

Table 2: Comparison of Teachers' Beliefs about

the Types of Assessment to Be Used in FL Classroom

\begin{tabular}{|l|c|c|c|c|c|}
\hline Country & $\mathbf{f ( n )}$ & & SD & F test & Comparison \\
\hline Turkey & 89 & 29.57 & 4.31 & \multirow{2}{*}{$\mathrm{F}(2,167)=0.161}$, & - \\
\hline Italy & 40 & 29.95 & 4.69 & $p=0.852$ & - \\
\hline Finland & 41 & 29.46 & 3.03 & & \\
\hline
\end{tabular}

As presented in Table 2, the results of ANOVA showed that teachers' beliefs about types of assessment to be used at $4^{\text {th }}$ grade FL classroom did not differ significantly in terms of country $[\mathrm{F}(2,167)==0.161, p=0.852]$.

Table 3: Turkish Teachers' Beliefs about the Types of Assessment

\begin{tabular}{|c|c|c|c|c|c|c|c|c|c|c|c|}
\hline \multirow[t]{2}{*}{ Items } & \multirow[t]{2}{*}{$x$} & \multicolumn{2}{|c|}{$\begin{array}{c}\text { I fully } \\
\text { agree }\end{array}$} & \multicolumn{2}{|c|}{$\begin{array}{c}\text { I } \\
\text { agree }\end{array}$} & \multicolumn{2}{|c|}{$\begin{array}{c}\text { I partially } \\
\text { agree }\end{array}$} & \multicolumn{2}{|c|}{$\begin{array}{c}\text { I don't } \\
\text { agree }\end{array}$} & \multicolumn{2}{|c|}{$\begin{array}{c}\text { I don't agree } \\
\text { at all }\end{array}$} \\
\hline & & $f(n)$ & $p(\%)$ & $f(n)$ & $p(\%)$ & $f(n)$ & $p(\%)$ & $f(n)$ & $\mathrm{p}(\%)$ & $f(n)$ & $p(\%)$ \\
\hline $\begin{array}{l}\text { My own-made paper } \\
\text { and pencil test }\end{array}$ & 3.87 & 28 & 31.5 & 34 & 38.2 & 17 & 19.1 & 8 & 9 & 2 & 2.2 \\
\hline $\begin{array}{l}\text { Standardized paper and pencil } \\
\text { test from the national or local } \\
\text { EFL education authority }\end{array}$ & 3.10 & 6 & 6.7 & 26 & 29.2 & 35 & 39.3 & 15 & 16.9 & 7 & 7.9 \\
\hline Performance-based test & 4.04 & 30 & 33.7 & 39 & 43.8 & 15 & 16.9 & 4 & 4.5 & 1 & 1.1 \\
\hline $\begin{array}{l}\text { Structured observation leading } \\
\text { to a written description of } \\
\text { students' performance }\end{array}$ & 3.43 & 13 & 14.6 & 31 & 34.8 & 31 & 34.8 & 10 & 11.2 & 4 & 4.5 \\
\hline Oral interview & 4.02 & 33 & 37.1 & 35 & 39.3 & 12 & 13.5 & 8 & 9 & 1 & 1.1 \\
\hline Language portfolio & 3.94 & 25 & 28.1 & 38 & 42.7 & 22 & 24.7 & 4 & 4.5 & - & - \\
\hline Self-assessment & 3.64 & 20 & 22.5 & 32 & 36 & 26 & 29.2 & 7 & 7.9 & 4 & 4.5 \\
\hline Peer-assessment & 3.50 & 19 & 21.3 & 27 & 30.3 & 27 & 30.3 & 12 & 13.5 & 4 & 4.5 \\
\hline
\end{tabular}

Table 4: Italian Teachers' Beliefs about the Types of Assessment

\begin{tabular}{|c|c|c|c|c|c|c|c|c|c|c|c|}
\hline \multirow[t]{2}{*}{ Items } & \multirow[t]{2}{*}{$x$} & \multicolumn{2}{|c|}{$\begin{array}{l}\text { I fully } \\
\text { agree }\end{array}$} & \multicolumn{2}{|c|}{$\begin{array}{c}\text { I } \\
\text { agree }\end{array}$} & \multicolumn{2}{|c|}{$\begin{array}{l}\text { I partially } \\
\text { agree }\end{array}$} & \multicolumn{2}{|c|}{$\begin{array}{l}\text { I don't } \\
\text { agree }\end{array}$} & \multicolumn{2}{|c|}{$\begin{array}{c}\text { I don't agree } \\
\text { at all }\end{array}$} \\
\hline & & $f(n)$ & $p(\%)$ & $f(n)$ & $p(\%)$ & $f(n)$ & $p(\%)$ & $f(n)$ & $p(\%)$ & $f(n)$ & $p(\%)$ \\
\hline $\begin{array}{l}\text { My own-made paper } \\
\text { and pencil test }\end{array}$ & 3.8 & 9 & 22.5 & 17 & 42.5 & 11 & 27.5 & 3 & 7.5 & - & \\
\hline $\begin{array}{l}\text { Standardized paper and pencil } \\
\text { test from the national or local } \\
\text { EFL education authority }\end{array}$ & 3.52 & 6 & 15 & 18 & 45 & 10 & 25 & 3 & 7.5 & 3 & 7.5 \\
\hline Performance-based test & 3.85 & 11 & 27.5 & 16 & 40 & 11 & 27.5 & - & & 2 & 5 \\
\hline $\begin{array}{l}\text { Structured observation leading } \\
\text { to a written description of } \\
\text { students' performance }\end{array}$ & 3.85 & 7 & 17.5 & 22 & 55 & 9 & 22.5 & 2 & 5 & - & - \\
\hline Oral interview & 4.42 & 20 & 50 & 19 & 47.5 & - & - & - & - & 1 & 2.5 \\
\hline Language portfolio & 3.2 & 7 & 17.5 & 12 & 30 & 11 & 27.5 & 2 & 5 & 8 & 20 \\
\hline Self-assessment & 3.75 & 9 & 22.5 & 19 & 47.5 & 8 & 20 & 1 & 2.5 & 3 & 7.5 \\
\hline Peer-assessment & 3.55 & 7 & 17.5 & 18 & 45 & 8 & 20 & 4 & 10 & 3 & 7.5 \\
\hline
\end{tabular}




\begin{tabular}{|c|c|c|c|c|c|c|c|c|c|c|c|}
\hline \multirow[t]{2}{*}{ Items } & \multirow[t]{2}{*}{$X$} & \multicolumn{2}{|c|}{$\begin{array}{l}\text { I fully } \\
\text { agree }\end{array}$} & \multicolumn{2}{|c|}{$\begin{array}{c}\text { I } \\
\text { agree }\end{array}$} & \multicolumn{2}{|c|}{$\begin{array}{l}\text { I partially } \\
\text { agree }\end{array}$} & \multicolumn{2}{|c|}{$\begin{array}{c}\text { I don't } \\
\text { agree }\end{array}$} & \multicolumn{2}{|c|}{$\begin{array}{c}\text { I don't agree } \\
\text { at all }\end{array}$} \\
\hline & & $f(n)$ & $p(\%)$ & $f(n)$ & $p(\%)$ & $f(n)$ & $p(\%)$ & $f(n)$ & $p(\%)$ & $f(n)$ & $p(\%)$ \\
\hline $\begin{array}{l}\text { My own-made paper } \\
\text { and pencil test }\end{array}$ & 4.26 & 17 & 41.5 & 18 & 43.9 & 6 & 14.6 & - & & - & - \\
\hline $\begin{array}{l}\text { Standardized paper and pencil } \\
\text { test from the national or local } \\
\text { EFL education authority }\end{array}$ & 2.65 & 3 & 7.3 & 6 & 14.6 & 12 & 29.3 & 14 & 34.1 & 6 & 14.6 \\
\hline Performance-based test & 3.48 & 4 & 9.8 & 16 & 39 & 17 & 41.5 & 4 & 9.8 & - & - \\
\hline $\begin{array}{l}\text { Structured observation leading } \\
\text { to a written description of } \\
\text { students' performance }\end{array}$ & 3.36 & 4 & 9.8 & 16 & 39 & 12 & 29.3 & 9 & 22 & - & - \\
\hline Oral interview & 4.02 & 11 & 26.8 & 21 & 51.2 & 8 & 19.5 & 1 & 2.4 & - & - \\
\hline Language portfolio & 3.75 & 6 & 14.6 & 22 & 53.7 & 10 & 24.4 & 3 & 7.3 & - & - \\
\hline Self-assessment & 4.26 & 18 & 43.9 & 17 & 41.5 & 5 & 12.2 & 1 & 2.4 & - & - \\
\hline Peer-assessment & 3.63 & 5 & 12.2 & 20 & 48.8 & 12 & 29.3 & 4 & 9.8 & - & - \\
\hline
\end{tabular}

\subsubsection{Beliefs about Content / Skill - Focus in Assessment}

Teachers were asked to indicate their beliefs about the content / skills - focus needed to be assessed for the $4^{\text {th }}$ grade students. The responses to beliefs items about content / skills - focus are given in Table 6, Table 7 and Table 8.

For Turkish teachers, based upon the mean average of the items, they tended to fully agree that the content / skills - focus needed to be assessed for $4^{\text {th }}$ graders were speaking skills $(=4.56)$ and listening skills $(=4.51)$. They agreed that the content / skills focus needed to be assessed were Lexis (vocabulary) $(=4.41)$, reading skills $(=4.26)$, pronunciation $(=4.14)$. They tended to agree on writing skills $(=3.82)$ and spelling $(=$ $3.75)$ and they tended to partially agree on grammar $(=2.96)$ as to be content / skill focuses needed to be assessed for $4^{\text {th }}$ graders.

For Italian teachers, based upon the mean average of the items, they tended to fully agree that the content / skills - focus needed to be assessed for $4^{\text {th }}$ graders were speaking skills $(=4.67)$, listening skills $(=4.67)$ and reading skills $(=4.52)$. They agreed that the content / skills - focus needed to be assessed were lexis (vocabulary) $(=4.4)$, pronunciation $(=4.2)$ and writing skills $(=4.17)$. They tended to agree on spelling $(=3.85)$ and grammar $(=3.7)$ as to be content $/$ skill - focuses needed to be assessed for $4^{\text {th }}$ graders. As for Finnish teachers, based upon the mean average of the items, they tended to fully agree that the content / skills - focus needed to be assessed for $4^{\text {th }}$ graders were Lexis (vocabulary) $(=4.60)$. They agreed that the content / skills - focus needed to be assessed were listening skills $(=4.41)$, speaking skills $(=4.36)$, reading skills $(=4.19)$ and writing skills $(=3.97)$. They tended to agree on pronunciation $(=3.8)$, grammar $(=3.78)$ and spelling $(=3.51)$ as to be content / skill - focuses needed to be assessed for $4^{\text {th }}$ graders. 
Table 6: Turkish Teachers' Beliefs about the Content / Skill - Focus in Assessment

\begin{tabular}{|l|c|c|c|c|c|c|c|c|c|c|c|}
\hline \multirow{2}{*}{ Items } & \multirow{2}{*}{$\mathbf{X}$} & \multicolumn{2}{|c|}{$\mathbf{F A}$} & \multicolumn{3}{|c|}{$\mathbf{A}$} & \multicolumn{3}{c|}{ PA } & \multicolumn{3}{c|}{ DA } & \multicolumn{2}{c|}{ DAA } \\
\cline { 3 - 12 } & & $\mathbf{f}(\mathbf{n})$ & $\mathbf{p}(\mathbf{\%})$ & $\mathbf{f ( n )}$ & $\mathbf{p}(\mathbf{\%})$ & $\mathbf{f ( n )}$ & $\mathbf{p}(\mathbf{\%})$ & $\mathbf{f ( n )}$ & $\mathbf{p}(\%)$ & $\mathbf{f}(\mathbf{n})$ & $\mathbf{p}(\%)$ \\
\hline Grammar & 2.96 & 7 & 7.9 & 21 & 23.6 & 34 & 38.2 & 16 & 18 & 11 & 12.4 \\
\hline Lexis (Vocabulary) & 4.41 & 45 & 50.6 & 36 & 40.4 & 8 & 9 & - & - & - & - \\
\hline Spelling & 3.75 & 26 & 29.2 & 27 & 30.3 & 25 & 28.1 & 10 & 11.2 & 1 & 1.1 \\
\hline Speaking skills & 4.59 & 61 & 68.5 & 20 & 22.5 & 8 & 9 & - & - & - & - \\
\hline Listening skills & 4.51 & 55 & 61.8 & 25 & 28.1 & 9 & 10.1 & - & - & - & - \\
\hline Reading skills & 4.26 & 43 & 48.3 & 29 & 32.6 & 16 & 18 & - & - & 1 & 1.1 \\
\hline Writing skills & 3.82 & 28 & 31.5 & 28 & 31.5 & 23 & 25.8 & 9 & 10.1 & 1 & 1.1 \\
\hline Pronunciation & 4.14 & 40 & 44.9 & 28 & 31.5 & 15 & 16.9 & 6 & 6.7 & - & - \\
\hline
\end{tabular}

Note: FA: I fully agree, A: I agree, PA: I partially agree, DA: I don't agree, DAA: I don't agree at all

Table 7: Italian Teachers' Beliefs about the Content / Skill - Focus in Assessment

\begin{tabular}{|l|c|c|c|c|c|c|c|c|c|c|c|}
\hline \multirow{2}{*}{ Items } & \multirow{2}{*}{$\mathbf{X}$} & \multicolumn{2}{|c|}{$\mathbf{F A}$} & \multicolumn{3}{|c|}{$\mathbf{A}$} & \multicolumn{3}{c|}{ PA } & \multicolumn{3}{c|}{ DA } & \multicolumn{2}{c|}{ DAA } \\
\cline { 3 - 13 } & & $\mathbf{f}(\mathbf{n})$ & $\mathbf{p}(\mathbf{\%})$ & $\mathbf{f}(\mathbf{n})$ & $\mathbf{p}(\mathbf{\%})$ & $\mathbf{f}(\mathbf{n})$ & $\mathbf{p}(\mathbf{\%})$ & $\mathbf{f}(\mathbf{n})$ & $\mathbf{p}(\mathbf{\%})$ & $\mathbf{f}(\mathbf{n})$ & $\mathbf{p}(\mathbf{\%})$ \\
\hline Grammar & 3.7 & 8 & 20 & 15 & 37.5 & 15 & 37.5 & 1 & 2.5 & 1 & 2.5 \\
\hline Lexis (Vocabulary) & 4.4 & 17 & 42.5 & 22 & 55 & 1 & 2.5 & - & - & - & - \\
\hline Spelling & 3.85 & 13 & 32.5 & 11 & 27.5 & 13 & 32.5 & 3 & 7.5 & - & - \\
\hline Speaking skills & 4.67 & 28 & 70 & 11 & 27.5 & 1 & 2.5 & - & - & - & - \\
\hline Listening skills & 4.67 & 29 & 72.5 & 9 & 22.5 & 2 & 5 & - & - & - & - \\
\hline Reading skills & 4.52 & 22 & 55 & 17 & 42.5 & 1 & 2.5 & - & - & - & - \\
\hline Writing skills & 4.17 & 16 & 40 & 16 & 40 & 7 & 17.5 & 1 & 2.5 & - & - \\
\hline Pronunciation & 4.2 & 18 & 45 & 13 & 32.5 & 8 & 20 & 1 & 2.5 & - & - \\
\hline
\end{tabular}

Note: FA: I fully agree, A: I agree, PA: I partially agree, DA: I don't agree, DAA: I don't agree at all

Table 8: Finnish Teachers' Beliefs about the Content / Skill - Focus in Assessment

\begin{tabular}{|c|c|c|c|c|c|c|c|c|c|c|c|}
\hline \multirow{2}{*}{ Items } & \multirow{2}{*}{$X$} & \multicolumn{2}{|c|}{ FA } & \multicolumn{2}{|c|}{ A } & \multicolumn{2}{|c|}{ PA } & \multicolumn{2}{|c|}{ DA } & \multicolumn{2}{|c|}{ DAA } \\
\hline & & $f(n)$ & $\mathrm{p}(\%)$ & $f(n)$ & $\mathrm{p}(\%)$ & $f(n)$ & $p(\%)$ & $f(n)$ & $\mathrm{p}(\%)$ & $f(n)$ & $p(\%)$ \\
\hline Grammar & 3.78 & 8 & 19.5 & 17 & 41.5 & 15 & 36.6 & 1 & 2.4 & - & - \\
\hline Lexis(Vocabulary) & 4.60 & 25 & 61 & 16 & 39 & - & & - & & - & - \\
\hline Spelling & 3.51 & 7 & 17.1 & 13 & 31.7 & 15 & 36.6 & 6 & 14.6 & - & - \\
\hline Speaking skills & 4.36 & 17 & 41.5 & 22 & 53.7 & 2 & 4.9 & - & & - & - \\
\hline Listening skills & 4.41 & 18 & 43.9 & 22 & 53.7 & 1 & 2.4 & - & & - & - \\
\hline Reading skills & 4.19 & 14 & 34.1 & 22 & 53.7 & 4 & 9.8 & 1 & 2.4 & - & - \\
\hline Writing skills & 3.97 & 12 & 29.3 & 13 & 31.7 & 15 & 36.6 & 1 & 2.4 & - & - \\
\hline Pronunciation & 3.8 & 9 & 22 & 19 & 46.3 & 9 & 22 & 4 & 9.8 & - & - \\
\hline
\end{tabular}

Note: FA: I fully agree, A: I agree, PA: I partially agree, DA: I don't agree, DAA: I don't agree at all

In order to examine whether teachers' beliefs about the content / skills - focus needed to be assessed for $4^{\text {th }}$ graders changed according to their country, one way analysis of variance (ANOVA) was performed. ANOVA results are given in Table 9. 
Table 9: Comparison of Teachers' Beliefs about

the Content / Skills - Focus Needed to Be Assessed for $4^{\text {th }}$ Graders

\begin{tabular}{|l|c|c|c|c|c|}
\hline Country & $\mathbf{f ( n )}$ & & SD & F test & Comparison \\
\hline Turkey & 89 & 32.48 & 4.43 & $\mathrm{~F}(2,167)=2.585$, & - \\
\hline Italy & 40 & 34.2 & 3.4 & $p=0.078$ & - \\
\hline Finland & 41 & 32.56 & 4.03 & & \\
\hline
\end{tabular}

As presented in Table 9, the results of ANOVA showed that teachers' beliefs about the content / skills - focus needed to be assessed for $4^{\text {th }}$ graders did not differ significantly in terms of country $[\mathrm{F}(2,167)=2.585, p=0.078]$

\subsubsection{Beliefs about the Kinds of Exercises}

Teachers were asked to indicate their beliefs about the kinds of exercises needed to be used for $4^{\text {th }}$ grade students. The responses to beliefs about the kinds of exercises needed to be used for $4^{\text {th }}$ grade students are given in Table 10, Table 11 and Table 12.

For Turkish teachers, based upon the mean average of the items, they agreed that the kinds of exercises needed to be used for $4^{\text {th }}$ graders were listening to audio material ( $=$ $4.43)$, matching $(=4.39)$, oral description of picture $(=4.28)$, role playing $(=4.26)$, making a dialogue $(=4.21)$, comprehension questions about a short test $(=4.17)$, filling gaps $(=$ 4.17). They tended to agree that students create their own sentences / text $(=3.77)$, writing words, short texts $(=3.73)$, reading words and sentences $(=3.69)$, students repeat vocabulary or sentences $(=3.67)$, spelling $(=3.59)$ and multiple choice $(=3.52)$ as to be kinds of exercises needed to be used for $4^{\text {th }}$ graders. They partially agree on dictation ( $=$ 3.22) and grammatical activities $(=3.03)$ needed to be used for $4^{\text {th }}$ graders.

For Italian teachers, based upon the mean average of the items, they agreed that the kinds of exercises needed to be used for $4^{\text {th }}$ graders were listening to audio material ( $=4.42)$, comprehension questions about a short test $(=4.26)$, fillings gaps $(=4.25)$, matching $(=4.25)$, oral description of a picture $(=4.2)$, multiple choice $(=4.15)$, role playing $(=4.1)$, writing words, short texts $(=4.05)$, reading words and sentences $(=3.97)$ and making a dialogue $(=3.97)$. They tended to agree on repeating vocabulary or sentences by students ( = 3.72), spelling $(=3.62)$, students' creation of their own sentences /texts $(=3.57)$, grammatical activities $(=3.55)$, and they partially agreed on dictation as to be kinds of exercises needed to be used for $4^{\text {th }}$ graders.

As for Finnish teachers, based upon the mean average of the items, they agreed that the kinds of exercises needed to be used for $4^{\text {th }}$ graders were listening to audio materials $(=4.34)$, students' creation of their own sentences /texts $(=4.29)$, comprehension questions about a short test $(=4.26)$, matching $(=4.12)$ and writing words, short texts $(=4.07)$, filling gaps $(=3.97)$ and grammatical activities $(=3.95)$. They tended to agree on oral description of a picture $(=3.75)$, reading words and sentences $(=$ 3.73), role playing $(=3.68)$ and making a dialogue $(=3.63)$, and they partially agreed on multiple choice $(=3.36)$, dictation $(=3.31)$ and repeating vocabulary or sentences by students $(=3)$. 
Nilay Ceylan Çakır, Zübeyde Sinem Genç

A COMPARATIVE ANALYSIS OF TEACHERS' BELIEFS ABOUT THE ASSESSMENT OF 4TH GRADE-EFL STUDENTS IN TURKEY, ITALY AND FINLAND

Table 10: Turkish Teachers' Beliefs about the Kinds of Exercises

\begin{tabular}{|c|c|c|c|c|c|c|c|c|c|c|c|}
\hline \multirow[t]{2}{*}{ Items } & & \multicolumn{2}{|c|}{$\begin{array}{l}\text { I fully } \\
\text { agree }\end{array}$} & \multicolumn{2}{|c|}{$\begin{array}{c}\text { I } \\
\text { agree }\end{array}$} & \multicolumn{2}{|c|}{$\begin{array}{c}\text { I partially } \\
\text { agree }\end{array}$} & \multicolumn{2}{|c|}{$\begin{array}{l}\text { I don't } \\
\text { agree }\end{array}$} & \multicolumn{2}{|c|}{$\begin{array}{c}\text { I don't } \\
\text { agree at all }\end{array}$} \\
\hline & & $f(n)$ & $p(\%)$ & $f(n)$ & $\mathrm{p}(\%)$ & $f(n)$ & $p(\%)$ & $f(n)$ & $p(\%)$ & $f(n)$ & $p(\%)$ \\
\hline Filing gaps & 4.17 & 33 & 37.1 & 41 & 46.1 & 13 & 14.6 & 2 & 2.2 & - & - \\
\hline Matching & 4.39 & 43 & 48.3 & 38 & 42.7 & 8 & 9 & - & - & - & - \\
\hline Role playing & 4.26 & 45 & 50.6 & 27 & 30.3 & 13 & 14.6 & 4 & 4.5 & - & - \\
\hline $\begin{array}{l}\text { Writing words, } \\
\text { short texts }\end{array}$ & 3.73 & 20 & 22.5 & 35 & 39.3 & 25 & 28.1 & 8 & 9 & 1 & 1.1 \\
\hline $\begin{array}{l}\text { Comprehension Qs } \\
\text { about a short text }\end{array}$ & 4.17 & 35 & 39.3 & 36 & 40.4 & 17 & 19.1 & 1 & 1.1 & - & - \\
\hline Dictation & 3.22 & 18 & 20.2 & 21 & 23.6 & 21 & 23.6 & 21 & 23.6 & 8 & 9 \\
\hline Grammatical activities & 3.03 & 7 & 7.9 & 19 & 21.3 & 38 & 42.7 & 20 & 22.5 & 5 & 5.6 \\
\hline $\begin{array}{l}\text { Students create their } \\
\text { own sentences/texts }\end{array}$ & 3.77 & 25 & 28.1 & 32 & 36 & 22 & 24.7 & 7 & 7.9 & 3 & 3.4 \\
\hline Listening to audio material & 4.43 & 48 & 53.9 & 33 & 37.1 & 7 & 7.9 & 1 & 1.1 & - & - \\
\hline Making a dialogue & 4.21 & 44 & 49.4 & 26 & 29.2 & 15 & 16.9 & 2 & 2.2 & 2 & 2.2 \\
\hline $\begin{array}{l}\text { Students repeat vocabulary } \\
\text { or sentences }\end{array}$ & 3.67 & 24 & 27 & 29 & 32.6 & 22 & 24.7 & 11 & 12.4 & 3 & 3.4 \\
\hline Multiple Choice & 3.52 & 16 & 18 & 35 & 39.3 & 21 & 23.6 & 14 & 15.7 & 3 & 3.4 \\
\hline Reading words and sentences & 3.69 & 22 & 24.7 & 28 & 31.5 & 31 & 34.8 & 6 & 6.7 & 2 & 2.2 \\
\hline Oral description of a picture & 4.28 & 43 & 48.3 & 31 & 34.8 & 12 & 23.5 & 3 & 3.4 & - & \\
\hline Spelling & 3.59 & 20 & 22.5 & 32 & 36 & 21 & 23.6 & 13 & 14.6 & 3 & 3.4 \\
\hline
\end{tabular}

Table 11: Italian Teachers' Beliefs about the Kinds of Exercises

\begin{tabular}{|c|c|c|c|c|c|c|c|c|c|c|c|}
\hline \multirow[t]{2}{*}{ Items } & & \multicolumn{2}{|c|}{$\begin{array}{l}\text { I fully } \\
\text { agree }\end{array}$} & \multicolumn{2}{|c|}{$\begin{array}{c}\text { I } \\
\text { agree }\end{array}$} & \multicolumn{2}{|c|}{$\begin{array}{l}\text { I partially } \\
\text { agree }\end{array}$} & \multicolumn{2}{|c|}{$\begin{array}{c}\text { I don't } \\
\text { agree }\end{array}$} & \multicolumn{2}{|c|}{$\begin{array}{c}\text { I don't } \\
\text { agree at all }\end{array}$} \\
\hline & & $f(n)$ & $p(\%)$ & $f(n)$ & $p(\%)$ & $f(n)$ & $p(\%)$ & $f(n)$ & $\mathrm{p}(\%)$ & $f(n)$ & $p(\%)$ \\
\hline Filing gaps & 4.25 & 13 & 32.5 & 24 & 60 & 3 & 7.5 & - & - & - & - \\
\hline Matching & 4.25 & 18 & 45 & 21 & 52.5 & 1 & 2.5 & - & - & - & - \\
\hline Role playing & 4.1 & 17 & 42.5 & 14 & 35 & 7 & 17.5 & - & - & 2 & 5 \\
\hline $\begin{array}{l}\text { Writing words, } \\
\text { short texts }\end{array}$ & 4.05 & 13 & 32.5 & 16 & 40 & 11 & 27.5 & - & - & - & - \\
\hline $\begin{array}{l}\text { Comprehension Qs } \\
\text { about a short text }\end{array}$ & 4.4 & 18 & 45 & 20 & 50 & 2 & 5 & - & - & - & - \\
\hline Dictation & 3 & 3 & 7.5 & 10 & 25 & 15 & 37.5 & 8 & 20 & 4 & 10 \\
\hline Grammatical activities & 3.55 & 7 & 17.5 & 13 & 32.5 & 16 & 40 & 3 & 7.5 & 1 & 2.5 \\
\hline $\begin{array}{l}\text { Students create their own } \\
\text { sentences/texts }\end{array}$ & 3.57 & 9 & 22.5 & 15 & 37.5 & 10 & 25 & 2 & 5 & 4 & 10 \\
\hline Listening to audio material & 4.42 & 24 & 60 & 11 & 27.5 & 3 & 7.5 & 2 & 5 & - & - \\
\hline Making a dialogue & 3.97 & 15 & 37.5 & 15 & 37.5 & 7 & 17.5 & - & - & 3 & 7.5 \\
\hline $\begin{array}{l}\text { Students repeat vocabulary } \\
\text { or sentences }\end{array}$ & 3.72 & 10 & 25 & 15 & 37.5 & 9 & 22.5 & 6 & 15 & - & - \\
\hline Multiple choice & 4.15 & 14 & 35 & 20 & 50 & 4 & 10 & 2 & 5 & - & - \\
\hline Reading words and sentences & 3.97 & 12 & 30 & 17 & 42.5 & 9 & 22.5 & 2 & 5 & - & - \\
\hline Oral description of a picture & 4.2 & 14 & 35 & 20 & 50 & 6 & 15 & - & - & - & - \\
\hline Spelling & 3.62 & 10 & 25 & 11 & 27.5 & 13 & 32.5 & 6 & 15 & - & - \\
\hline
\end{tabular}




\begin{tabular}{|c|c|c|c|c|c|c|c|c|c|c|c|}
\hline \multirow[t]{2}{*}{ Items } & & \multicolumn{2}{|c|}{$\begin{array}{l}\text { I fully } \\
\text { agree }\end{array}$} & \multicolumn{2}{|c|}{$\begin{array}{c}\text { I } \\
\text { agree }\end{array}$} & \multicolumn{2}{|c|}{$\begin{array}{l}\text { I partially } \\
\text { agree }\end{array}$} & \multicolumn{2}{|c|}{$\begin{array}{l}\text { I don't } \\
\text { agree }\end{array}$} & \multicolumn{2}{|c|}{$\begin{array}{c}\text { I don't agree at } \\
\text { all }\end{array}$} \\
\hline & & $f(n)$ & $p(\%)$ & $f(n)$ & $p(\%)$ & $f(n)$ & $\mathrm{p}(\%)$ & $f(n)$ & $p(\%)$ & $f(n)$ & $p(\%)$ \\
\hline Filing gaps & 3.97 & 10 & 24.4 & 21 & 51.2 & 9 & 22 & 1 & 2.4 & - & - \\
\hline Matching & 4.12 & 10 & 24.4 & 26 & 63.4 & 5 & 12.2 & - & - & - & - \\
\hline Role playing & 3.68 & 5 & 12.2 & 19 & 46.3 & 16 & 39 & 1 & 2.4 & - & - \\
\hline $\begin{array}{l}\text { Writing words, } \\
\text { short texts }\end{array}$ & 4.07 & 11 & 26.8 & 22 & 53.7 & 8 & 19.5 & - & - & - & - \\
\hline $\begin{array}{l}\text { Comprehension Qs } \\
\text { about a short text }\end{array}$ & 4.26 & 15 & 36.6 & 22 & 53.7 & 4 & 9.8 & - & - & - & - \\
\hline Dictation & 3.31 & 4 & 9.8 & 15 & 36.6 & 12 & 29.3 & 10 & 24.4 & - & - \\
\hline Grammatical activities & 3.95 & 10 & 24.4 & 19 & 46.3 & 12 & 29.3 & - & - & - & - \\
\hline $\begin{array}{l}\text { Students create their own } \\
\text { sentences/texts }\end{array}$ & 4.29 & 16 & 39 & 21 & 51.2 & 4 & 9.8 & - & - & - & - \\
\hline Listening to audio material & 4.34 & 16 & 39 & 24 & 58.5 & - & - & 1 & 2.4 & - & - \\
\hline Making a dialogue & 3.63 & 8 & 19.5 & 14 & 34.2 & 15 & 36.6 & 4 & 9.8 & - & - \\
\hline $\begin{array}{l}\text { Students repeat vocabulary } \\
\text { or sentences }\end{array}$ & 3 & 5 & 12.2 & 9 & 22 & 11 & 26.8 & 13 & 31.7 & 3 & 7.3 \\
\hline Multiple Choice & 3.36 & 5 & 12.2 & 10 & 24.4 & 23 & 56.1 & 1 & 2.4 & 2 & 4.9 \\
\hline Reading words and sentences & 3.73 & 8 & 19.5 & 20 & 48.8 & 7 & 17.1 & 6 & 14.6 & - & - \\
\hline Oral description of a picture & 3.75 & 7 & 17.1 & 19 & 46.3 & 13 & 31.7 & 2 & 4.9 & - & - \\
\hline Spelling & 3.43 & 5 & 12.2 & 15 & 36.6 & 14 & 34.1 & 7 & 17.1 & - & - \\
\hline
\end{tabular}

In order to examine whether teachers' beliefs about kinds of exercises needed to be used for $4^{\text {th }}$ grade students changed according to their country, one way analysis of variance (ANOVA) was performed. ANOVA results are given in Table 13.

Table 13: Comparison of Teachers' Beliefs about the Kinds of Exercises Needed to Be Used for $4^{\text {th }}$ Grade Students

\begin{tabular}{|l|c|c|c|c|c|}
\hline Country & $\mathbf{N}$ & & SD & F test & Comparison \\
\hline Turkey & 89 & 58.21 & 7.74 & $\mathrm{~F}(2,167)=1.081$, & - \\
\hline Italy & 40 & 59.42 & 7.4 & $p=0.342$ & - \\
\hline Finland & 41 & 56.95 & 7.35 & & \\
\hline
\end{tabular}

As presented in Table 13, the results of ANOVA showed that teachers' beliefs about the kinds of exercises needed to be used for $4^{\text {th }}$ grade students did not differ significantly in terms of country $[\mathrm{F}(2,167)=1.081, p=0.342]$.

\subsubsection{Teachers' General Beliefs about Assessment of Students' Foreign Language}

The teachers were asked to indicate their general beliefs about assessment of $4^{\text {th }}$ grade students' foreign language. The responses to the items are given in Table 14, Table 15 and Table 16.

For Turkish teachers, mean scores of their general beliefs of students' foreign language were between $=4.68$ and $=2.97$. The item of "It is difficult to assess speaking skills in the crowded classes" had the highest mean score whereas the item of "The results of assessment should be used to place students" had the lowest mean score. Other items' mean scores were respectively; there should be ready-made exams in the books to assess listening skills $(=4.19)$, students should be assessed to check students strength and 
weaknesses for lesson planning $(=3.98)$, parents should always be informed with the results of students' assessment $(=3.97)$, there should be ready-made exams in the books to assess speaking skills ( = 3.93), students should be assessed by comments, not by numerical grades $(=3.66)$, I need to be more trained in assessing students in primary schools ( = 3.48), students of a foreign language should be assessed in the primary school (=3.26), students should be assessed to provide a record for success and failure $(=3.24)$, and students should be tested on sentence-level activities $(=3.15)$.

For Italian teachers, mean scores of their general beliefs of students' foreign language were between $=4.2$ and $=3.45$. The item of "Students of a foreign language should be assessed in the primary school" had highest mean score whereas the item of "The results of assessment should be used to place students" had the lowest mean score. Other items' mean scores were respectively; there should be ready-made exams in the books to assess listening skills $(=4.15)$, students should be assessed to check students strength and weaknesses for lesson planning $(=4.15)$, there should be ready-made exams in the books to assess speaking skills $(=4.15)$, parents should always be informed with the results of students' assessment ( = 3.92), I need to be more trained in assessing students in primary schools $(=3.72)$, It is difficult to assess speaking skills in the crowded classes $(=3.7)$, students should be tested on sentence-level activities $(=3.7)$, students should be assessed to provide a record for success and failure $(=3.67)$ and students should be assessed by comments, not by numerical grades $(=3.62)$.

For Finnish teachers, mean scores of their general beliefs of students' foreign language were between $=4.26$ and $=1.87$. The item of "There should be ready-made exams in the books to assess listening skills" had highest mean score whereas the item of "The results of assessment should be used to place students" had the lowest mean score. Other items' mean scores were respectively; students of a foreign language should be assessed in the primary school $(=4.2)$, there should be ready-made exams in the books to assess speaking skills $(=4.12)$, there should be ready-made exams in the books to assess listening skills ( $=4$ ), parents should always be informed with the results of students' assessment $(=4.07)$, I need to be more trained in assessing students in primary schools $(=3.97)$, students should be assessed to check students strength and weaknesses for lesson planning ( = 3.68), students should be tested on sentence-level activities ( = 3.68), students should be assessed by comments, not by numerical grades $(=3.29)$, it is difficult to assess speaking skills in the crowded classes (=3.09) and students should be assessed to provide a record for success and failure (=2.92).

Table 14: Turkish Teachers' General Beliefs about Assessing 4th Grade Students' Foreign Language

\begin{tabular}{|l|c|c|c|c|c|c|c|c|c|c|c|}
\hline \multirow{2}{*}{ Items } & & \multicolumn{2}{|c|}{$\mathbf{F A}$} & \multicolumn{2}{|c|}{$\mathbf{A}$} & \multicolumn{2}{|c|}{ PA } & \multicolumn{2}{c|}{ DA } & \multicolumn{2}{c|}{ DAA } \\
\cline { 3 - 11 } & $\mathbf{f}(\mathbf{n})$ & $\mathbf{p}(\mathbf{\%})$ & $\mathbf{f}(\mathbf{n})$ & $\mathbf{p}(\mathbf{\%})$ & $\mathbf{f}(\mathbf{n})$ & $\mathbf{p}(\%)$ & $\mathbf{f}(\mathbf{n})$ & $\mathbf{p}(\%)$ & $\mathbf{f}(\mathbf{n})$ & $\mathbf{p}(\%)$ \\
\hline $\begin{array}{l}\text { Students of a foreign language } \\
\text { should be assessed in the primary } \\
\text { school. }\end{array}$ & 3.26 & 18 & 20.2 & 14 & 15.7 & 39 & 43.8 & 10 & 11.2 & 8 & 9 \\
\hline $\begin{array}{l}\text { I need to be more trained in assessing } \\
\text { students in primary schools. }\end{array}$ & 3.48 & 14 & 15.7 & 35 & 39.3 & 22 & 24.7 & 16 & 18 & 2 & 2.2 \\
\hline
\end{tabular}


Nilay Ceylan Çakır, Zübeyde Sinem Genç

A COMPARATIVE ANALYSIS OF TEACHERS' BELIEFS ABOUT THE ASSESSMENT

OF 4TH GRADE-EFL STUDENTS IN TURKEY, ITALY AND FINLAND

\begin{tabular}{|l|l|l|l|l|l|l|l|l|l|l|l|}
\hline $\begin{array}{l}\text { It is difficult to assess speaking skills } \\
\text { in the crowded classes. }\end{array}$ & 4.68 & 65 & 73 & 21 & 23.6 & 2 & 2.2 & 1 & 1.1 & - \\
\hline $\begin{array}{l}\text { There should be ready-made exams } \\
\text { in the books to assess listening skills. }\end{array}$ & 4.19 & 33 & 37.1 & 43 & 48.3 & 11 & 12.4 & 1 & 1.1 & 1 & 1.1 \\
\hline $\begin{array}{l}\text { Students should be assessed to check } \\
\text { students' strength and weaknesses } \\
\text { for lesson planning }\end{array}$ & 3.98 & 29 & 32.6 & 39 & 43.8 & 15 & 16.9 & 3 & 3.4 & 3 & 3.4 \\
\hline $\begin{array}{l}\text { Students should be assessed by } \\
\text { comments, not by numerical grades. }\end{array}$ & 3.66 & 20 & 22.5 & 30 & 33.7 & 30 & 33.7 & 7 & 7.9 & 2 & 2.2 \\
\hline $\begin{array}{l}\text { The results of assessment should be } \\
\text { used to place students. }\end{array}$ & 2.97 & 10 & 11.2 & 22 & 24.7 & 24 & 27 & 22 & 24.7 & 11 & 12.4 \\
\hline $\begin{array}{l}\text { There should be ready-made exams } \\
\text { in the books to assess speaking skills. }\end{array}$ & 3.93 & 28 & 31.5 & 34 & 38.2 & 20 & 22.5 & 7 & 7.9 & - & - \\
\hline $\begin{array}{l}\text { Students should be assessed to } \\
\text { provide a record for success and } \\
\text { failure. }\end{array}$ & 3.24 & 13 & 14.6 & 26 & 29.2 & 28 & 31.5 & 14 & 15.7 & 8 & 9 \\
\hline $\begin{array}{l}\text { Students should be tested on } \\
\text { sentence-level activities. }\end{array}$ & 3.15 & 8 & 9 & 28 & 31.5 & 31 & 34.8 & 14 & 15.7 & 8 & 9 \\
\hline $\begin{array}{l}\text { Parents should always be informed } \\
\text { with the results of students' } \\
\text { assessment. }\end{array}$ & 3.97 & 30 & 33.7 & 35 & 39.3 & 17 & 19.1 & 6 & 6.7 & 1 & 1.1 \\
\hline
\end{tabular}

Note: FA : I fully agree, A: I agree, PA: I partially agree, DA: I don't agree, DAA: I don't agree at all

Table 15: Italian Teachers' General Beliefs about Assessing 4th Grade Students' Foreign Language

\begin{tabular}{|c|c|c|c|c|c|c|c|c|c|c|c|}
\hline \multirow{2}{*}{ Items } & & \multicolumn{2}{|c|}{ FA } & \multicolumn{2}{|c|}{ A } & \multicolumn{2}{|c|}{ PA } & \multicolumn{2}{|c|}{ DA } & \multicolumn{2}{|c|}{ DAA } \\
\hline & & $f(n)$ & $p(\%)$ & $f(n)$ & $\mathrm{p}(\%)$ & $f(n)$ & $\mathrm{p}(\%)$ & $f(n)$ & $p(\%)$ & $f(n)$ & $p(\%)$ \\
\hline $\begin{array}{l}\text { Students of a foreign language } \\
\text { should be assessed in the primary } \\
\text { school. }\end{array}$ & 4.2 & 13 & 32.5 & 22 & 55 & 5 & 12.5 & - & - & - & - \\
\hline $\begin{array}{l}\text { I need to be more trained in assessing } \\
\text { students in primary schools. }\end{array}$ & 3.72 & 12 & 30 & 14 & 35 & 9 & 22.5 & 1 & 2.5 & 4 & 10 \\
\hline $\begin{array}{l}\text { It is difficult to assess speaking skills } \\
\text { in the crowded classes. }\end{array}$ & 3.7 & 13 & 32.5 & 13 & 32.5 & 7 & 17.5 & 3 & 7.5 & 4 & 10 \\
\hline $\begin{array}{l}\text { There should be ready-made exams } \\
\text { in the books to assess listening skills. }\end{array}$ & 4.15 & 11 & 27.5 & 25 & 62.5 & 3 & 7.5 & 1 & 2.5 & - & - \\
\hline $\begin{array}{l}\text { Students should be assessed to check } \\
\text { students' strength and weaknesses } \\
\text { for lesson planning }\end{array}$ & 4.15 & 14 & 35 & 19 & 47.5 & 6 & 15 & 1 & 2.5 & - & - \\
\hline $\begin{array}{l}\text { Students should be assessed by } \\
\text { comments, not by numerical grades. }\end{array}$ & 3.62 & 11 & 27.5 & 12 & 30 & 11 & 27.5 & 3 & 7.5 & 3 & 7.5 \\
\hline $\begin{array}{l}\text { The results of assessment should be } \\
\text { used to place students. }\end{array}$ & 3.45 & 2 & 5 & 20 & 50 & 12 & 30 & 6 & 15 & - & - \\
\hline $\begin{array}{l}\text { There should be ready-made exams } \\
\text { in the books to assess speaking skills. }\end{array}$ & 4.15 & 14 & 35 & 19 & 47.5 & 6 & 15 & 1 & 2.5 & - & - \\
\hline $\begin{array}{l}\text { Students should be assessed to } \\
\text { provide a record for success and } \\
\text { failure. }\end{array}$ & 3.67 & 6 & 15 & 19 & 47.5 & 11 & 27.5 & 4 & 10 & - & - \\
\hline $\begin{array}{l}\text { Students should be tested on } \\
\text { sentence-level activities. }\end{array}$ & 3.7 & 2 & 5 & 26 & 65 & 10 & 25 & 2 & 5 & - & - \\
\hline $\begin{array}{l}\text { Parents should always be informed } \\
\text { with the results of students' } \\
\text { assessment. }\end{array}$ & 3.92 & 14 & 35 & 14 & 35 & 8 & 20 & 3 & 7.5 & 1 & 2.5 \\
\hline
\end{tabular}

Note: FA: I fully agree, A: I agree, PA: I partially agree, DA: I don't agree, DAA: I don't agree at all 
Table 16: Finnish Teachers' General Beliefs about Assessing 4th Grade Students' Foreign Language

\begin{tabular}{|c|c|c|c|c|c|c|c|c|c|c|c|}
\hline \multirow{2}{*}{ Items } & & \multirow{2}{*}{$\begin{array}{l}\text { FA } \\
\text { f(n) }\end{array}$} & \multirow[b]{2}{*}{$p(\%)$} & \multicolumn{2}{|c|}{ A } & \multicolumn{2}{|c|}{ PA } & \multicolumn{2}{|c|}{ DA } & \multicolumn{2}{|c|}{ DAA } \\
\hline & & & & $f(n)$ & $\mathrm{p}(\%)$ & $f(n)$ & $\mathrm{p}(\%)$ & $f(n)$ & $\mathrm{p}(\%)$ & $f(n)$ & $p(\%)$ \\
\hline $\begin{array}{l}\text { Students of a foreign language } \\
\text { should be assessed in the } \\
\text { primary school. }\end{array}$ & 3.97 & 13 & 31.7 & 16 & 39 & 11 & 26.8 & - & - & 1 & 2.4 \\
\hline $\begin{array}{l}\text { I need to be more trained in } \\
\text { assessing students in primary } \\
\text { schools. }\end{array}$ & 3.09 & 6 & 14.6 & 11 & 26.8 & 7 & 17.1 & 15 & 36.6 & 2 & 4.9 \\
\hline $\begin{array}{l}\text { It is difficult to assess speaking } \\
\text { skills in the crowded classes. }\end{array}$ & 4 & 17 & 41.5 & 11 & 26.8 & 9 & 22 & 4 & 9.8 & - & - \\
\hline $\begin{array}{l}\text { There should be ready-made } \\
\text { exams in the books to assess } \\
\text { listening skills. }\end{array}$ & 4.26 & 18 & 43.9 & 17 & 41.5 & 5 & 12.2 & 1 & 2.4 & - & - \\
\hline $\begin{array}{l}\text { Students should be assessed to } \\
\text { check students' strength and } \\
\text { weaknesses for lesson planning }\end{array}$ & 3.68 & 8 & 19.5 & 14 & 34.1 & 17 & 41.5 & 2 & 4.9 & - & - \\
\hline $\begin{array}{l}\text { Students should be assessed by } \\
\text { comments, not by numerical } \\
\text { grades. }\end{array}$ & 3.29 & 4 & 9.8 & 14 & 34.1 & 13 & 31.7 & 10 & 24.4 & - & - \\
\hline $\begin{array}{l}\text { The results of assessment should } \\
\text { be used to place students. }\end{array}$ & 1.87 & - & - & 1 & 2.4 & 7 & 17.1 & 19 & 46.3 & 14 & 34.1 \\
\hline $\begin{array}{l}\text { There should be ready-made } \\
\text { exams in the books to assess } \\
\text { speaking skills. }\end{array}$ & 4.12 & 15 & 36.6 & 17 & 41.5 & 8 & 19.5 & 1 & 2.4 & - & - \\
\hline $\begin{array}{l}\text { Students should be assessed to } \\
\text { provide a record for success and } \\
\text { failure. }\end{array}$ & 2.92 & 3 & 7.3 & 10 & 24.4 & 13 & 31.7 & 11 & 26.8 & 4 & 9.8 \\
\hline $\begin{array}{l}\text { Students should be tested on } \\
\text { sentence-level activities. }\end{array}$ & 3.68 & 4 & 9.8 & 23 & 56.1 & 11 & 26.8 & 3 & 7.3 & - & - \\
\hline $\begin{array}{l}\text { Parents should always be } \\
\text { informed with the results of } \\
\text { students' assessment. }\end{array}$ & 4.07 & 16 & 39 & 13 & 31.7 & 11 & 26.8 & 1 & 2.4 & - & - \\
\hline
\end{tabular}

Note: FA: I fully agree, A: I agree, PA: I partially agree, DA: I don't agree, DAA: I don't agree at all

In order to examine whether teachers' general beliefs about assessment of $4^{\text {th }}$ grade students' foreign language changed according to their country, one way analysis of variance (ANOVA) was performed. ANOVA results are given in Table 17.

Table 17: Comparison of Teachers' General Beliefs about Assessing $4^{\text {th }}$ Grade Students' Foreign Language

\begin{tabular}{|l|c|c|c|c|c|}
\hline Country & $\mathbf{N}$ & & SD & F test & Comparison \\
\hline Turkey & 89 & 40.57 & 5.99 & $\mathrm{~F}(2,167)=3.962$, \\
$p<0.05$ & Italy $>$ Finland \\
\hline Italy & 40 & 42.45 & 5.62 & & \\
\hline Finland & 41 & 39.0 & 4.2 & & \\
\hline
\end{tabular}

As presented in Table 17, the results of ANOVA showed that teachers' general beliefs about assessment of $4^{\text {th }}$ grade students' foreign language differed significantly in terms of country $[\mathrm{F}(2,167)=3.962, p<0.05]$. Follow up analysis using post hoc comparison with Tukey test was conducted to observe pair-wise differences among the countries. The post 
hoc analysis showed that Italian teachers' general beliefs about assessment of $4^{\text {th }}$ grade students' foreign language $(=42.45, \mathrm{SD}=5.62)$ was significantly higher than Finnish teachers' general beliefs $(=39.0, \mathrm{SD}=4.2)$.

\section{Discussion}

The research question was addressed in terms of the teachers' beliefs about assessment of 4 th grade students in Turkey, Finland and Italy.

Turkish teachers agreed that performance based - tests and oral interviews as assessment tools; speaking skills, listening skills, lexis (vocabulary), reading skills and pronunciation as content / skills in assessment; and audio material, matching, oral description of picture, role playing, making a dialogue, comprehension questions about a short test, filling gaps as the kinds of assessment were needed to be used at $4^{\text {th }}$ grade language classes.

Italian teachers agreed that oral interview as an assessment tool; speaking skills, listening skills and reading skills as content / skill - focus in assessment; and listening to audio material, matching, oral description of picture, role playing, making a dialogue, comprehension questions about a short test and filling gaps were needed to be used at $4^{\text {th }}$ grade language classes.

Finnish teachers agreed that self-assessment, teacher own-made paper and pencil test and oral interview as assessment tools; lexis (vocabulary), listening skills, speaking skills, reading skills and writing skills as content / skill - focus in assessment; and audio materials, students' creation of their own sentences/texts, comprehension questions about a short test, matching and writing words, short texts, filling gaps and grammatical activities were needed to be used at $4^{\text {th }}$ grade language classes.

Turkish, Italian and Finnish teachers' beliefs about assessment revealed their tendency to use more students-centered and formative-based assessment procedures. Writing skills and associated assessment tools and exercises were observed to be given less attention by many of the teachers in all three countries. The reason of giving less or little attention to writing skills is because of the fact that writing skills are not the main focus of $4^{\text {th }}$ grade language learning. Speaking and listening skills are more emphasized and the main focus in the language curriculum for $4^{\text {th }}$ grade level. That is why teachers showed higher beliefs about the tools, content - skills and communicative exercises associated with listening and speaking skills. However, Finnish teachers, compared with Italian and Turkish, put much more emphasis on writing skills along with associated tools, content and exercises. Teachers' beliefs and tendencies regarding the ways of assessment tools, the types of content-skills and exercises are in line with the language proficiency to be gathered in A1 and / or A2 level according to CERF. Teachers' general beliefs about assessment of young learners' foreign language revealed that the items of the results of assessment should be used to place students had the lowest belief scores for most of the teachers. 
In all three countries, most of the teachers indicated that assessing speaking skills in crowded classes is difficult. Britton (2015) asserts that implementation of assessment of learning in EFL is closely related to the context in which it is done and also connected with timing, learner characteristics (ages, stages of cognitive development) and curriculum.

\section{Recommendations}

This study has revealed some critical implications for teachers' beliefs and further research in terms of assessment of young learners.

For further research, more teachers from more different countries should be invited to a similar study to portray teachers' practices and beliefs in Turkey and different European Countries. Even though European countries follow CEFR standards for language learning, they still stick to their countries' educational policy. Comparing different countries in terms of teachers' assessment beliefs could also help to understand how educational policy and teacher orientation effect their practices. In the following studies, teachers' demographic characteristics (gender, age, experience, school type etc.), attributes (e.g. motivation) and philosophy (e.g. curriculum orientation) should also be included as factors to understand the relationship of these factors with teachers' assessment practices and beliefs. Furthermore, in order to deepen our understanding on how teachers implement assessment in their classroom, the rationale behind their practice and the factors affecting their practice, comparative case studies should be conducted through not only using questionnaire but also using a series of observation (e.g. video study) and teacher documents.

\section{Conclusion}

The quantitative analyses revealed significant outcomes with regard to foreign language teachers' beliefs about assessment of young language learners in language classes in Turkey, Italy and Finland. The following conclusions have been reached throughout the study.

1) The highest belief score about the types of assessment to be used for $4^{\text {th }}$ grade students for Turkish teachers was related with the item of "performance-based test", for Italian teachers was related with the item of "oral interview", and for Finnish teachers was related with the item of "my own-made paper and pencil test" and "self-assessment".

2) The highest belief score about the content / skills needed to be assessed for $4^{\text {th }}$ grade students for Turkish teachers was related with the item of "speaking skills", for Italian teachers was related with the item of "speaking and listening skills" and for Finnish teachers was related with the item of "lexis (vocabulary)". 
3) The highest belief score about the kinds of exercises needed to be used for $4^{\text {th }}$ grade students for Turkish, Italian and Finnish teachers was the same and related with the item of "listening to audio material".

4) Teachers' beliefs about the types of assessment to be used, about the content and skills needed to be assessed and about the kinds of exercises needed to be used for $4^{\text {th }}$ grade students did not differ significantly across the countries.

5) The highest belief score about assessment of young learners' foreign language for Turkish teachers was related with the item of "It is difficult to assess speaking skills in the crowded classes", for Italian teachers was related with the items of "Students of a foreign language should be assessed in the primary school" and for Finnish teachers was related with the item of "There should be ready exams in the books to assess listening skills". Italian teachers' general beliefs about assessment of young learners' foreign language were significantly higher than Finnish teachers.

6) Teachers in three countries tended to use ready-to-use exams drawn not only from text books but also from online platforms.

7) Considering the teachers in all three countries, most of the teachers believed that students of a foreign language should be assessed to provide a record for success and failure in the primary school and parents should always be informed with the results of students' assessment.

8) Most of the teachers in three countries are against the use of assessment results to place students.

9) In all countries, teachers' lack of assessment skills was a common deficiency which needs to be improved.

\section{Limitations of the Study}

This study was carried out with only language teachers in Turkey and two European countries, Finland and Italy. Face-to-face interaction with Turkish teachers was implemented in the administration of the questionnaires. However, the same procedures were not implemented with Italian and Finnish teachers. They were contacted through internet (e.g. teacher platform) and were required to give their responses that way. This might have provided comfort to the participants, but it probably decreased the reliability of the questionnaire because some teachers experienced problems with some questions.

Teachers' beliefs regarding the assessment practices in EFL classes were only based on self-reported data which was not assured with real class observations. Thus, teachers' self-report might not totally reflect what was being assessed and might somehow reflect teachers' goodwill.

EFL teachers from only three countries were selected to address to the research questions. This helped to understand teachers' beliefs in these countries. The effect of school conditions, demographics and curriculum orientations of teachers on their beliefs were not compared in this study due to the scope of the investigation. 


\section{Conflict of Interest Statement}

The authors declare no conflicts of interests.

\section{About the Authors}

Nilay Ceylan Çakır, is an English Language Teacher with 11 years of experience and she has been working as a project coordinator in İznik District Directorate of National Education for 4 years. Her bachelor degrees are English Language Teaching (ELT) in Uludag University, Sociology in Anadolu University and Web Design and Coding in Anadolu University. Her master's degree is English Language Teaching in Uludag University. Her main interest is writing and impelementing local, national and international projects and has participated in several EU-funded projects. She was the project manager in TÜBİTAK 4007- The Gate From Tradition to Future; İznik Science Fest held in 17-18-19th June 2021. Currently, she is the project manager in Erasmus+ Ka201 Strategic partnership project on "Enhancing Creative and Innovative Teaching Skills Through Training and Observation".

Zübeyde Sinem Genç is a full professor at the Department of English Language Teaching, Bursa Uludağ University in Turkey. She has Ph.D. degree in TESOL and Composition from Indiana University of Pennsylvania, USA. She has been teaching undergraduate and graduate courses on foreign language teaching. She also taught academic English at the Language Center, IUP, and graduate courses at MA in Applied Linguistics program at Southern Illinois University. Her professional interests include pre- and in-service language teacher education, second language acquisition and technology in foreign language teaching and learning. She has been involved in research projects and published articles, book chapters and books on foreign language teacher education, second language acquisition, and teaching English as a foreign language. Currently, she is the Head of the Department of Foreign Languages Education at Bursa Uludağ University.

\section{References}

Alberta Education (2008). Spanish language and culture nine-year program: Grade 4 classroom assessment material. Alberta, Canada: Alberta Education, Learning and Teaching $\begin{array}{llll}\text { Resources. } & \text { Retrieved } & \text { o9.02.1019 from }\end{array}$ https://files.eric.ed.gov/fulltext/ED506103.pdf

Anandan, K. (2015). Assessment for learning. Bharathidasan University: Centre for Distance Education. Retrieved on 13.01.2019 from www.bdu.ac.in/cde/docs/ebooks/BEd/I/ASSESSMENT\%20FOR\%20LEARNING.pdf

Anderson, R. S. (1998). Why talk about different ways to grade? The shift from traditional assessment to alternative assessment. New Directions for Teaching and Learning, 74, Jossey-Bass Publishers 
Ayas, N. (2014). An investigation of teachers' conception and practices concerning assessment in English for young learners classroom. (Unpublished Master Thesis) Çağ University, Institute of Social Sciences, Mersin.

Britton, A. M. (2015). Assessment for learning in teaching English to young learners: Teachers' understanding, classroom practice and impact on interaction. Unpublished Doctoral Dissertation, University of Reading. Retrieved on 10.02.2019 from http://centaur.reading.ac.uk/41939/1/21803102 Britton thesis.pdf

Broadfoot, P., \& Black, P. (2004). Redefining assessment? The first ten years of assessment in education, Assessment in Education: Principles, Policy E Practice, 11(1), 7-26, doi: $10.1080 / 0969594042000208976$

Brown, G. T. L. (2008). Conceptions of assessment: Understanding what assessment means to teachers and students. New York, NY: Nova Science Publishers.

Brumen M., Cagran B. \& Rixon S.(2009) Comparative assessment of young learners' foreign language competence in three Eastern European countries, Educational Studies, 35:3, 269-295, doi: 10.1080/03055690802648531

Büyükkarcl, K. (2010). The effect of formative assessment on learners' text anxiety and assessment preferences in EFL context. Doctoral thesis, Çukurova University, the Institute of Social Science, Adana

Chan, Y-C. (2008). Elementary school EFL teachers' beliefs and practice of multiple assessments. Reflecting on English Language Teaching, 7(1), 37-62.

Council of Europe (2001). Common European Framework of References: Learning, teaching, assessment. Strasbourg: Language Policy Unit. Retrieved on 16.02.2019 from www.coe.int/lang-CEFR.

Cumming, A. (2009). Language assessment in education: Tests, curricula, and teaching. Annual Review of Applied Linguistics, 29, 90-100. doi: https://doi.org/10.1017/S0267190509090084

Davison, C., \& Cummins, J. (2007). Assessment and evaluation in ELT: Shifting paradigms and practices. In J. Cummins and C. Davison (Eds.), International Handbook of English Language Teaching (pp. 415 - 420). New York: Springer.

Dochy, F. (2001). A new era: Different needs, new challenges. Research Dialogue in Learning and Instruction 2 (2001), 11-20.

Doğandere, İ. C. (2006). Perspectives of young learners of English towards assessment: Formative or summative?. Unpublished Master Thesis, Uludağ University, The Institute of Social Sciences, Bursa.

Fulcher, G., \& Davidson, F. (2007). Language testing and assessment: An advanced resource book. London: Routledge.

Gattullo, F. (2000). Formative assessment in ELT primary (elementary) classrooms. An Italian case study. Language Testing, 17(2), 278-288. doi: $10.1177 / 026553220001700210$

Gökçe, Ö. F. (2014). A comparison of EFL teachers' perception of formative assessment in public and private schools. Unpublished Master Thesis, Çağ University, Institute of Social Sciences, Mersin. 
Griffiths, T. , Gore, J., \& Ladwig, J. (2006, November). Teachers' fundamental beliefs, commitment to reform and the quality of pedagogy. Paper presented at Proceedings Australian Association for Research in Education Annual Conference, Adelaide.

Guskey, T. R. (2002). Professional development and teacher change. Teachers and Teaching, 8(3), 381 - 391. doi: 10.1080/135406002100000512

Halali, A. A. S., Singh, H. K. D., Saeed, I. M., \& Making Z. (2017). Teachers' perceptions toward the use of classroom-based assessment in English reading. International Journal of Education and Research, 5(11), 153-168.

Jannati, S. (2015). ELT teachers' language assessment literacy: Perceptions and practices. Educational Research Association The International Journal of Research in Teacher Education, 6(2), 26-37.

Jia, Y., Eslami, Z. R., \& Burlbaw, L. M. (2006). ESL teachers' perceptions and factors influencing their use of classroom-based reading assessment. Bilingual Research Journal, 30(2), 407 - 430. doi: 10.1080/15235882.2006.10162883

Johnson, K. E. (1992). The relationship between teachers' beliefs and practices during literacy instruction for non-native speakers of English. Journal of Reading Behavior, 24(1), 83-108. doi: $10.1080 / 10862969209547763$

Ioannou - Georgiou, S. (2003). Assessing young learners (Resource books for teachers).Oxford: OUP.

Kibar, E. P. (2018). Pre-service and in-service English teachers perceptions of testing and assessment in EFL classes. Unpublished Master Thesis, Hacettepe University, Institute of Educational Sciences, Ankara.

Kırkgöz, Y. and Ağçam, R. (2012). Investigating the written assessment practices of Turkish teachers of English at primary education. The Journal of Language and Linguistic Studies, 8 (2), 119-136. Retrieved on 09.02.2019 from http://www.jlls.org/vol8no2/119-136.pdf

Kırkgöz, Y., Babanoğlu, M. P., \& Ağçam, R. (2017). Turkish EFL teachers' perceptions and practices of foreign language assessment in primary education. Journal of Education and e-Learning Research, 4(4), 163-170.

Lamprianou, I., \& Athanasou, J.A. (2009). A teacher's guide to educational assessment. Rottherdam: Sense Publishers.

Liljedahl, P. (2010). The four purposes of assessment. Vector (Summer), 7-12. Retrieved on 15.01.2019 from www.peterliljedahl.com/wp.../4-Purposes-of-Assessment.pdf

MEB - Milli Eğitim Bakanlığı (2018). İngilizce dersi öğretim programı (İlkokul ve Ortaokul 2, 3, 4, 5, 6, 7 ve 8. Sinuflar). Ankara: Milli Eğitim Bakanlı̆̆ı.

Mertler, C. A. (1998, October). Classroom assessment practices of Ohio teachers. Paper presented at the meeting of the Mid-Western Educational Research Association, Chicago, IL. Retrieved on 06.02.2019 from https://files.eric.ed.gov/fulltext/ED428085.pdf

Nasab, F. G. (2015). Alternative versus traditional assessment. Journal of Applied Linguistics and Language Research, 2(6), 165-178. 
Önalan, O., \& Karagül, A.E. ( 2018). A study on Turkish EFL teachers' beliefs about assessment and its different uses in teaching English. Journal of Language and Linguistic Studies, 14(3), 190-201.

Öz, H. (2014). Turkish teachers' practices of assessment for learning in the English as a foreign language classroom. Journal of Language Teaching and Research, 5(4), 775785.

Pajares, M. F. (1992). Teachers' beliefs and educational research: Cleaning up a messy construct. Review of Educational Research, 62 (3), 307-332. doi: 10.2307/1170741

Palomba, C. \& Banta, T. W. (1999). Assessment essentials: Planning, implementing, and improving assessment in higher education. Jossey-Bass Publishers: San Francisco.

Rea-Dickins, P. (2004). Understanding teachers as agents of assessment. Language Testing 21(3), 249-258. doi: 10.1191/02655322041t283ed

Remesal, A. (2011). Primary and secondary teachers' conceptions of assessment: A qualitative study. Teaching and Teacher Education, 27(2), 472-482. Retrieved from https://doi.org/10.1016/j.tate.2010.09.017"/j.tate.2010.09.017

Şahinkarakaş, S. (2012). The role of teaching experience on teachers' perceptions of language assessment. Procedia - Social and Behavioral Sciences 47, 1787-1792.

Shim, K. N. (2009). An investigation into teachers' perceptions of classroom-based assessment of English as a foreign language in Korean primary education. Unpublished Doctoral Dissertation, University of Exeter, Exeter. Retrieved on 08.02.2019 from https://ore.exeter.ac.uk/repository/bitstream/handle/10036/.../ShimKN.doc..pdf?... $\underline{2}$

Song, E., \& Koh, K. (22-27 August 2010). Assessment for learning: Understanding teachers' beliefs and practices. Paper presented at the 36th International Association for Educational Assessment (IAEA) Annual Conference in Bangkok, Thailand. Retrieved on 06.02.2019 from https://repository.nie.edu.sg/handle/10497/16733

Tatll, L. (2014). EFL teachers' attitudes toward teaching English to young learners. Unpublished Master Thesis, Çă̆ University, Institute of Social Sciences, Mersin.

Thomas, M. (2012). Teachers' beliefs about classroom assessment and their selection of classroom assessment strategies. Journal of Research and Reflections in Education, 6(2), $103-112$

Veal, M. L. (1988). Pupil assessment perceptions and practices of secondary teachers. Journal of Teaching in Physical Education, 7 (4), 327-42. doi: 10.1123/jtpe.7.4.327

Wewer, T. (2014). Assessment of young learners' English proficiency in bilingual content instruction CLIL. Unpublished Doctoral Dissertation, University of Turku, Turku, Finland.

Wiesnerová, D. (2012). Benefits of self-assessment in English classes at elementary schools. Bachelor Thesis, Masaryk University Brno. Retrieved on 15.01.2019 from https://is.muni.cz/th/h8x8n/Bachelor Thesis Wiesnerova.pdf 
Nilay Ceylan Çakır, Zübeyde Sinem Genç

A COMPARATIVE ANALYSIS OF TEACHERS' BELIEFS ABOUT THE ASSESSMENT

OF 4TH GRADE-EFL STUDENTS IN TURKEY, ITALY AND FINLAND

Creative Commons licensing terms

Author(s) will retain the copyright of their published articles agreeing that a Creative Commons Attribution 4.0 International License (CC BY 4.0) terms will be applied to their work. Under the terms of this license, no permission is required from the author(s) or publisher for members of the community to copy, distribute, transmit or adapt the article content, providing a proper, prominent and unambiguous attribution to the authors in a manner that makes clear that the materials are being reused under permission of a Creative Commons License. Views, opinions, and conclusions expressed in this research article are views, opinions, and conclusions of the author(s). Open Access Publishing Group and European Journal of Foreign Language Teaching shall not be responsible or answerable for any loss, damage, or liability caused in relation to/arising out of conflicts of interest, copyright violations, and inappropriate or inaccurate use of any kind content related or integrated into the research work. All the published works are meeting the Open Access Publishing requirements and can be freely accessed, shared, modified, distributed, and used in educational, commercial, and non-commercial purposes under a Creative Commons Attribution 4.0 International License (CC BY 4.0). 